\title{
Towards a Universal Law Controlling all Human Cancer Chromosome LOH Deletions, Perspectives in Prostate and Breast Cancers screening
}

\author{
Jean-Claude Perez* \\ Retired interdisciplinary researcher (IBM), France
}

Submission: October 23, 2017; Published: January 09, 2018

"Correspondence Address: Jean-Claude Perez, Retired interdisciplinary researcher (IBM), £ 7 avenue de terre-rouge F33127 Martignas Bordeaux metropole France, Email: jeanclaudeperez2@gmail.com

\begin{abstract}
Background: Global analysis of 3 human genomes of increasing levels of evolution (Neanderthal /Sapiens Build34/Sapiens hg38) reveals 2 levels of numerical constraints controlling, structuring and optimizing these genome's DNA sequences. A global constraint - called "HGO" for "Human Genome Optimum" - optimizes the genome at its global scale. The same operator applied to each of the 24 individual chromosomes reveals a hierarchical structure of these 24 chromosomes.

Methods: We analyze how this HGO genomic optimum is perturbed by hundred single or multiple LOH (Loss of Heterozygosity) deletions relating to different chromosomes and cancers.

Results: The generic law highlighted is stated as: "When an LOH deletion affects a chromosome upstream of the HGO point (chromosomes 4 13...) in the chromosomal spectrum, this deletion degrades the genomic optimum of the cancer genome. When an LOH deletion affects a chromosome downstream of the HGO point (chromosomes 19 22...) In the chromosomal spectrum, this deletion improves the genomic optimum of the cancer genome. The exhaustive analysis of the 240 LOHs for the following 6 cases: Chromosome 13 (breast cancer), chromosome 5 (breast cancer), chromosome 10 (glioblastoma cancer), chromosome 1 (colorectal cancer), chromosome 1 (neuroblastoma cancer) and chromosome 16 (prostate cancer) obey this law in 227 cases and do not obey this law for 13 cases (success rate of our law $=94.58 \%$ ). In this article we will detail this type of analysis on $153 \mathrm{LOH}$ relating to breast and prostate tumors affecting respectively chromosome 13, chromosome 5 (breast) and chromosome 16 (prostate). In this detailed study, the HGO law described here is verified in 143 cases out of 153, or 93.46\% of favorable cases.

Conclusion: The main application of this fundamental discovery will be the genomic characterization and classification of tumors, making it possible to predict the dangerousness and even the pathogenicity.

Keywords : Human genome; Cancer; Loss of Heterozygosity; Biomathematics; Evolution
\end{abstract}

\section{Introduction}

"The demonstration of an" Human Genome Optimum" through the comparative analysis of genomes to varying degrees of evolution and the study of the hierarchical structure of the 24 individual chromosomes is of great importance. It has led you to a new classification of tumors to prioritize their pathogenicity, which is also remarkable."

Professor François Gros Pasteur Institute Paris (co-discoverer of messenger RNA with James Watson and Walter Gilbert). Thanks to the CRISPR (Clustered regularly interspaced short palindromic repeats) technology, it is now possible to locally modify the genomes, and particularly the human genome [1]. Almost simultaneously, the fractal and global structures of the human genome were demonstrated [2]. In such a context, apart from ethical questions, can a local technology as powerful as CRISPR be applied, ignoring its possible effect on the possible global and long- range equilibria and balancing at the chromosome scale or even the entire genome scale? For more than 25 years, we have been looking for possible global, even numerical, structures that would organize DNA, genes, chromosomes and even whole genomes [3-6]. Curiously, the method of numerical analysis of whole genomes as well as the discovery of a global law of impact of the LOH deletions associated with tumors that will be the subject of this article may seem to the reader too simple or even "naive"... In effect, these laws are based on a well-known type of analysis that could be thought to have explored all aspects: the analysis of GC / TA ratios. It has long been known that such ratios [7].

Characterize the diversity of chromosomes. Under the name of "isochores," Giorgio Bernardi has extensively explored its richness and diversity $[8,9]$. We have already demonstrated a numerical structure at the scale of each human chromosome as well as on 


\section{Cancer Therapy \& Oncology International Journal}

the whole genome [10-13]. In [10] we have already highlighted this numerical value of 0.6909830056 , the HGO in this article: it controls the population of triplets' codons analysing single stranded DNA sequence from the whole human genome. However, it is only by deepening the notion of "fractal periodicity", outlined in [14], and we will highlight in various articles in preparation [15] that we have re-discovered the major role that this GC / TA ratio at the whole chromosome and whole genome scales. Particularly, in 2015, we have demonstrated [14] how a global structure organizes any DNA sequence. This numerical organization is based on the atomic masses of the " $G$ " bases of the double stranded DNA sequence, therefore on the bases $C$ and $G$ of the single stranded DNA sequence. Here is another reason sufficient to consider the relations and proportions between bases $\mathrm{C}+\mathrm{G}$ on the one hand, and $\mathrm{T}+\mathrm{A}$ on the other hand. Comparing the three genomes of reference of Neanderthal [15,16], Sapiens Build34 of 2003 [17] and Sapiens hg38 of 2013 [18], we will demonstrate in the evidence of "Fractals periods "and "resonance periods" characterizing each of the 24 human chromosomes. It is for these simple reasons that we have decided to focus on these $\mathrm{C}+\mathrm{G} / \mathrm{T}+\mathrm{A}$ ratios at the scale of each of the 24 human chromosomes as well as on the whole genome analyzing the 46 chromosomes single stranded DNA sequences.

\section{Materials and Methods}

\section{Analysed whole human Genomes}

We analyzed completely and systematically each of the 24 chromosomes of each of the following three reference genomes:

\section{a) Neanderthal genome}

Neanderthal genome (2014) [16]

b) Sapiens Build34 (2003) human reference genome [17]

Sapiens Build34 (2003) genome

c) Sapiens HG38 (2013) human reference genome [18]

Sapiens HG38 (2013) genome

\section{Computing the HGOs}

Let us now distinguish the three types of HGO that will be discussed:

\begin{tabular}{|c|c|c|c|}
\hline \multicolumn{1}{|c|}{ Chromosome } & $\mathrm{C}+\mathrm{G}$ & $\mathrm{T}+\mathrm{A}$ & $(\mathrm{C}+\mathrm{G}) /(\mathrm{T}+\mathrm{A})$ \\
\hline & \multicolumn{1}{|c|}{ Chromosomes UPSTREAM HGO point $=(3-\mathrm{Phi}) \div 2=0.6909830056$} \\
\hline 4 & 72568001 & $1.17 \mathrm{E}+08$ & 0.619262 \\
\hline 13 & 37772797 & 60210328 & 0.627347 \\
\hline 5 & 71611274 & $1.1 \mathrm{E}+08$ & 0.653065 \\
\hline $\mathrm{X}$ & 61221521 & 93671508 & 0.653577 \\
\hline 6 & 67360020 & $1.03 \mathrm{E}+08$ & 0.655773 \\
\hline 3 & 78577742 & $1.2 \mathrm{E}+08$ & 0.657431 \\
\hline 18 & 31856106 & 48233499 & 0.660456 \\
\hline
\end{tabular}

A. Theoretical HGO (tHGO) tHGO = $(3-\mathrm{PHI}) \div 2=$ 0.6909830056, where $\mathrm{PHI}$ is the Golden Ratio $\mathrm{PHI}=$ 1.618033989

B. Reference woman HGO (rwHGO): rwHGO = 0.6913477936

error $($ tHGO - rwHGO) $=0.6909830056-0.6913477936=$ -0.0003647879784 and

Reference man HGO (rmHGO) : $\quad$ rmHGO $=0.6922864236$

error $($ tHGO - rmHGO) $=0.6909830056-0.6922864236=$ $-0.001303417973$

C. HGO ( $\mathrm{LOH})$ is considered as a function: with $\mathrm{LOH}$ the deletion disturbing the computed CG/TA whole human genomic ratio and « $\mathrm{n}$ » the LOH partially deleted chromosome and « chrs » all chromosomes from 1 to 22 which are different with « $\mathrm{n} »$. HGO is computed by compiling $\mathrm{C}+\mathrm{G}$ and $\mathrm{T}+\mathrm{A}$ nucleotides populations from each 46 chromosomes DNA single strand.

Example: HGOwoman $(\mathrm{LOH} \mathrm{chr} n)=(\mathrm{C}+\mathrm{G}$ population from 46 chromosomes strand 1$)+(\mathrm{C}+\mathrm{G}$ population from 46 chromosomes strand1)] [ $(\mathrm{T}+\mathrm{A}$ population from 46 chromosomes strand1) $+(\mathrm{T}+\mathrm{A}$ population from 46 chromosomes strand1) ] Then:

HGOwoman $(\mathrm{LOH}$ chr $\mathrm{n})=[$ (sum $\mathrm{C}+\mathrm{G}$ single strand 1 to 22 chromosomes except chrn $)+($ sum $\mathrm{C}+\mathrm{G}$ chrn $)+($ sum $\mathrm{C}+\mathrm{G}$ chrX $)+$ (sum $\mathrm{C}+\mathrm{G}$ single strand 1 to 22 chromosomes except chrn) $+($ sum $\mathrm{C}+\mathrm{G}$ chr $\mathrm{LOH} \mathrm{n})+($ sum $\mathrm{C}+\mathrm{G}$ chrX $)][$ (sum $\mathrm{T}+\mathrm{A}$ single strand 1 to 22 chromosomes except chrn $)+($ sum $\mathrm{T}+\mathrm{A}$ chrn $)+($ sum $\mathrm{T}+\mathrm{A}$ chrX) (sum $\mathrm{T}+\mathrm{A}$ single strand 1 to 22 chromosomes except chrn) $+($ sum $\mathrm{T}+\mathrm{A} \operatorname{chr} \mathrm{LOH} \mathrm{n})+($ sum $\mathrm{T}+\mathrm{A}$ chrX $)]$ HGOman $(\mathrm{LOH}$ chr $\mathrm{n})$ $=[$ (sum $\mathrm{C}+\mathrm{G}$ single strand 1 to 22 chromosomes except chrn $)+$ $($ sum $\mathrm{C}+\mathrm{G}$ chrn $)+($ sum $\mathrm{C}+\mathrm{G}$ chrX $)+($ sum $\mathrm{C}+\mathrm{G}$ single strand 1 to 22 chromosomes except chrn $)+($ sum $\mathrm{C}+\mathrm{G}$ chr LOH n) $+($ sum $\mathrm{C}+\mathrm{G}$ chrY) ] [ (sum $\mathrm{T}+\mathrm{A}$ single strand 1 to 22 chromosomes except chrn) $+($ sum $\mathrm{T}+\mathrm{A}$ chrn $)+($ sum $\mathrm{T}+\mathrm{A}$ chrX) $($ sum $\mathrm{T}+\mathrm{A}$ single strand 1 to 22 chromosomes except chrn $)+($ sum $\mathrm{T}+\mathrm{A} \operatorname{chr} \mathrm{LOH} \mathrm{n})+($ sum $\mathrm{T}+\mathrm{A}$ chrY) ]

Recall the single stranded $\mathrm{C}+\mathrm{G}, \mathrm{T}+\mathrm{A}$ and individual chromosome HGO values (Table 1). Example of LOH effect on the HGO, the case of a single $\mathrm{LOH}$ deletion in chromosome 13 breast tumor (Table 2).
Table 1: CG values, TA values and CG/TA ratio for each Sapiens HG38 individual chromosome. 


\section{Cancer Therapy \& Oncology International Journal}

\begin{tabular}{|c|c|c|c|}
\hline 8 & 58133960 & 86634176 & 0.671028 \\
\hline 2 & 96769083 & $1.44 \mathrm{E}+08$ & 0.67304 \\
\hline 7 & 64696843 & 94273288 & 0.686269 \\
\hline 12 & 54275482 & 78862334 & 0.688231 \\
\hline 14 & 36982791 & 53585358 & 0.690166 \\
\hline \multicolumn{3}{|c|}{ Chromosomes DOWNSTREAM HGO point $=(3-\mathrm{Phi}) \div 2=0.6909830056$} \\
\hline 11 & 16411625 & 23676994 & 0.693146 \\
\hline 11 & 50270473 & 71520077 & 0.702886 \\
\hline 10 & 55885058 & 78648684 & 0.710566 \\
\hline 15 & 55359481 & 77903481 & 0.710616 \\
\hline 20 & 96166571 & $1.34 \mathrm{E}+08$ & 0.715981 \\
\hline 16 & 35578844 & 49062481 & 0.725174 \\
\hline 17 & 28010605 & 35933652 & 0.779509 \\
\hline 19 & 36472718 & 45333225 & 0.804547 \\
\hline
\end{tabular}

Example of $\mathrm{LOH}$ effect on the HGO, the case of a single LOH deletion in chromosome 13 breast tumor:

Table 2: Computing HGO ratio disturbed by a sample LOH on Chr13 Breast tumor (see results for more details).

\begin{tabular}{|c|c|c|c|c|c|c|c|}
\hline \multicolumn{2}{|c|}{$\begin{array}{c}\text { LOH references:number / } \\
\text { ref number in published figure / } \\
\text { Markers Id. }\end{array}$} & \multicolumn{2}{|c|}{ Deleted LOH regions } & \multicolumn{2}{|c|}{ Woman Genome XX } & \multicolumn{2}{|c|}{ Man Genome XY } \\
\hline \multirow{5}{*}{\multicolumn{2}{|c|}{$\begin{array}{l}\text { Reference Human Genome } \\
\qquad \text { (HG38 2013) }\end{array}$}} & & & Reference & Error & Reference & Error \\
\hline & & & & HGO & ideal HGO & HGO & ideal HGO - \\
\hline & & & & 0.691348 & - reference & & reference \\
\hline & & & & & HGO & 0.692286 & HGO \\
\hline & & & & & -0.00036 & & -0.0013 \\
\hline \multicolumn{8}{|l|}{ Region A } \\
\hline 2 & 4 & \multirow{2}{*}{33097286} & \multirow{2}{*}{33790250} & \multirow{2}{*}{0.691352} & \multirow{2}{*}{-0.000369150} & \multirow{2}{*}{0.692291} & -0.00130799 \\
\hline D13S1694 & D13S267 & & & & & & 0 \\
\hline
\end{tabular}

\section{Computing Detailed Steps}

First, the case of a whole woman XX genome:

HGOwoman $(\mathrm{LOH}$ chr $\mathrm{n})=[$ (sum $\mathrm{C}+\mathrm{G}$ single strand 1 to 22 chromosomes except chrn $)+($ sum $\mathrm{C}+\mathrm{G}$ chrn $)+($ sum $\mathrm{C}+\mathrm{G}$ chrX $)+$ (sum $\mathrm{C}+\mathrm{G}$ single strand 1 to 22 chromosomes except chrn) + (sum $\mathrm{C}+\mathrm{G} \operatorname{chr} \mathrm{LOH} \mathrm{n})+($ sum $\mathrm{C}+\mathrm{G} \operatorname{chrX})][$ (sum $\mathrm{T}+\mathrm{A}$ single strand 1 to 22 chromosomes except chrn $)+($ sum $\mathrm{T}+\mathrm{A}$ chrn $)+($ sum $\mathrm{T}+\mathrm{A}$ chrX $)$ (sum $\mathrm{T}+\mathrm{A}$ single strand 1 to 22 chromosomes except chrn) + (sum $\mathrm{T}+\mathrm{A} \operatorname{chr} \mathrm{LOH} \mathrm{n})+(\operatorname{sum} \mathrm{T}+\mathrm{A} \operatorname{chrX})]($ sum $\mathrm{C}+\mathrm{G}$ single strand 1 to 22 chromosomes except chr13) CG1T022 : 9616657196769083 785777427256800171611274673600206469684358133960 5027047355359481558850585427548203698279135578844 364727183757544431856106280157122801060516411625 18406838 cumulating CUMCG : 1090984671 (sum T+A single strand 1 to 22 chromosomes except chr13) : TA1T022 : $134314441 \quad 143779145 \quad 119522393 \quad 117184666 \quad 109654104$ 1027185029427328886634176715200777790348178648684
7886233405358535849062481453332254534476048233499 30425046359336522367699420752939 cumulating CUMTA: 567363245 .

(sum $\mathrm{C}+\mathrm{G} \operatorname{chr} 13)$ :

CGR13 : 37772797

(sum $\mathrm{T}+\mathrm{A} \operatorname{chr} 13)$ :

TAR13; 60210328

$(\operatorname{sum} \mathrm{C}+\mathrm{G} \operatorname{chrX})$ :

CGX : 61221521

(sum $\mathrm{C}+\mathrm{G}$ chrY) :

CGY : $\quad 10572683$

(sum $\mathrm{T}+\mathrm{A} \operatorname{chrX})$ :

TAX : 93671508

(sum $\mathrm{T}+\mathrm{A} \operatorname{chrY}$ ) :

TAY : $\quad 15842360$

(sum C+G chr 13 LOH ) : CGLOH : 37498415

(sum T+A chr 13 LOH) : TALOH : 59791746

computing the HGO LOH ratio: HGOWLOH $=(($ CUMCG + CGR13 + CGX $)+($ CUMCG + CGLOH + CGX $)) \div(($ CUMTA + TAR13 + TAX $)$ $+($ CUMTA + TALOH + TAX $))$ 


\section{HGOWLOH: $\quad 0.6913521525$}

\section{Detailed intermediary steps:}

HGOWLOH: 0.6913521525

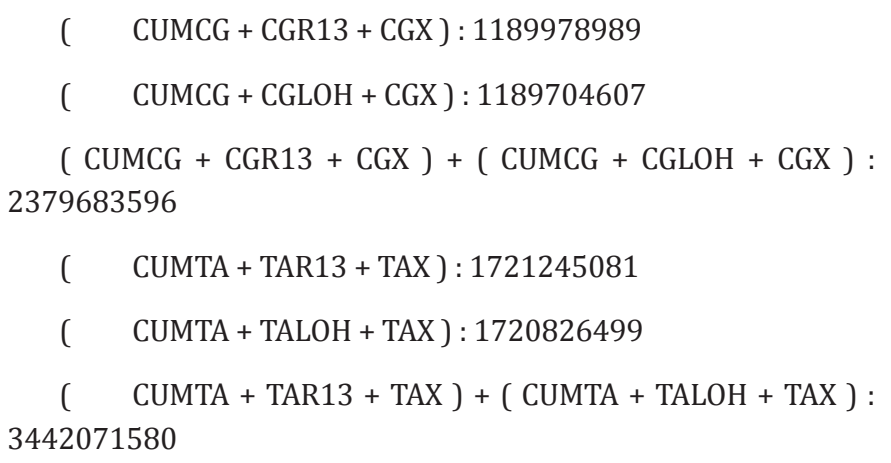

Now the same summarized computing in the case of a XY man whole genome: HGOman ( $\mathrm{LOH}$ chr $\mathrm{n})=$

[ (sum $\mathrm{C}+\mathrm{G}$ single strand 1 to 22 chromosomes except chrn) + (sum $\mathrm{C}+\mathrm{G}$ chrn $)+($ sum $\mathrm{C}+\mathrm{G} \operatorname{chrX})+($ sum $\mathrm{C}+\mathrm{G}$ single strand 1 to 22 chromosomes except chrn $)+($ sum $\mathrm{C}+\mathrm{G}$ chr LOH n $)+($ sum $\mathrm{C}+\mathrm{G}$ chrY) ] [ (sum $\mathrm{T}+\mathrm{A}$ single strand 1 to 22 chromosomes except chrn) $+($ sum $\mathrm{T}+\mathrm{A}$ chrn $)+($ sum $\mathrm{T}+\mathrm{A} \operatorname{chrX})($ sum $\mathrm{T}+\mathrm{A}$ single strand 1 to 22 chromosomes except chrn $)+($ sum $\mathrm{T}+\mathrm{A}$ chr LOH n $)+($ sum $\mathrm{T}+\mathrm{A}$ chrY $)] \mathrm{HGOMLOH}=((\mathrm{CUMCG}+\mathrm{CGR} 13+\mathrm{CGX})+(\mathrm{CUMCG}+\mathrm{CGLOH}$ + CGY $)) \div(($ CUMTA + TAR13 + TAX $)+($ CUMTA + TALOH + TAY $))$ HGOMLOH: 0.6922910002 CUMCG + CGR13 + CGX ) : 1189978989 CUMCG + CGLOH + CGY ) : $1139055769($ CUMCG + CGR13 + CGX ) $+($ CUMCG + CGLOH + CGY $): 2329034758$ CUMTA + TAR13 + TAX ) $: 1721245081$ CUMTA + TALOH + TAY ) $: 1642997351$ CUMTA + TAR13 + TAX $)+($ CUMTA + TALOH + TAY $): 3364242432$

\section{Computing Errors i.e. Distances}

\section{LOH XX genome:}

\section{$0.6913521525^{-0} 0.0003691469064$}

Recall reference XX genome:

0.6913477936 $-0.0003647879784$

$\begin{array}{cccc}\text { Error: abs } & \left({ }^{0} 0.0003691469064\right) & > & \text { abs } \\ \left({ }^{0} 0.0003647879784\right) & \end{array}$

Then decreasing woman HGO for this $\mathrm{LOH}$ in chromosome13 located upstream to the swapping HGO point. LOH XY genome: $0.6922910002^{-} 0.001307994526$.

Recall reference XY genome: $\quad 0.692228642236$ $-0.001303417973$

$\begin{array}{cccc}\text { Error: abs } & (-0.001307994526) & > & \text { abs } \\ (-0.001303417973) & \end{array}$

Then decreasing man HGO for this LOH in chromosome13 located upstream to the swapping HGO point.

\section{Results}

In all that follows, the general methodology will be as follows: we calculate, for the 46 chromosomes constituting each genome studied, only the single-stranded DNA sequences. In these sequences, we count the relative populations of bases $\mathrm{T}+\mathrm{A}$ on the one hand, and $\mathrm{C}+\mathrm{G}$ on the other hand.

\section{HGO of the 3 whole genomes: Neanderthal, Sapiens Build34 and Sapiens HG38}

The three genomes we compare here are differentiated on the one hand by their respective evolution levels, on the other hand by the sample of individual genomes of which they form the syntheses, and finally by the precision of the sequencing of DNA. For example, this work by the Craig Venter team demonstrates this level of dispersion between more than 10,000 individual genomes and reference genomes such as HG28 [19].

The 3 analysed genomes are:

i. Neanderthal genome (2014) [16]

ii. Sapiens Build34 (2003) genome [17]

iii. Sapiens hg38 (2013) genome [18]

The methods of computing the different HGOs are given in "supporting information part 1". The detailed information on the calculation of the respective HGOs at the level of each chromosome and of the whole genomes can be found in "supporting information part 2". The detailed data related to the 3 whole genomes shows the various distances and errors between real computed HGOs for each genome and theoretical HGO optimum value $=0.6909830055$. Particularly, it is found that the $3 \mathrm{HGOs}$ calculated for the respective 3 genomes of Neanderthal, Sapiens (2003 Build34 and 2013 hg38 Sapiens) are very close to the ideal theoretical optimal HGO = 0.6909830056 ( $99.67 \%$ for the least optimal genome).

It is also observed that female genomes (XX) are more optimal than male genomes (XY). On the other hand, the genomes of Neanderthal and Sapiens (Build34 of 2003) have very close optimization levels. We believe these results from the fact that the precisions of their respective DNA sequencing are similar. On the contrary, the hg38 genomes of 2013 show the most optimal levels, this is most certainly due to the deeper quality of their DNA sequencing. Figure 1 summarises HGO results for these 3 human genomes of varying levels of evolution. Table 6 in "supporting information part 2" summarizes the HGO values, absolute and relative errors in both cases of man or human whole genomes for the 3 human genomes compared.

\section{HGO spectral hierarchy of the 24 Human chromosomes}

The following Figures illustrate the hierarchical spectrum of the individual HGOs of each of the 24 chromosomes for each of the three genomes analyzed. It should be noted that the upstream / downstream tipping point lies between chromosomes 14 and 21 , which is closely related to the probable mechanisms explaining trisomy 21 (whose disorders involve precisely these two chromosomes). Finally, we note that it is the downstream region that contributes the most to the superiority of optimality of sapiens hg38 compared to sapiens Build34. However, a more detailed 


\section{Cancer Therapy \& Oncology International Journal}

analysis of the upstream and downstream regions shows that when passing from sapiens Build34 2003 to hg38 2013, the notorious optimization obeys the global strategy law of the $\mathrm{LOH}$. Also of note is that 20 out of 24 chromosomes are $0 \mathrm{~K}$, with the exception of chromosomes $13, \mathrm{X}, \mathrm{Y}$, and 1 . The law presented here states that there is reduction of optimality for upstream chromosomes and improvement of optimality for downstream regions.

It is therefore remarkable that this is the same and only law which seems to simultaneously control two domains as different as: 1) the global strategy of LOH deletions of tumors on the one hand and 2) the difference of evolution of the same genome following two increasing precision levels of DNA sequencing (Build34 2003 and hg38 2013) on the other! In "supporting information part 2, Tables 7- 9" (HGO spectral hierarchy of the 24 Human chromosomes:

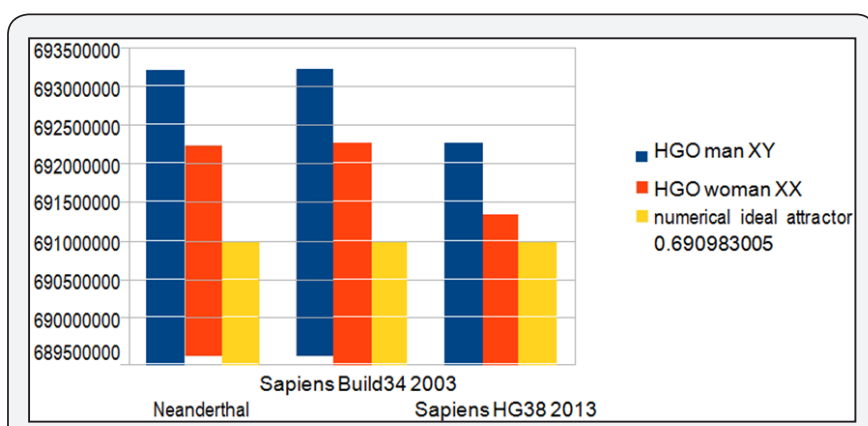

Figure 1: The respective HGOs of 3 human genomes of varying levels of evolution are shown here.

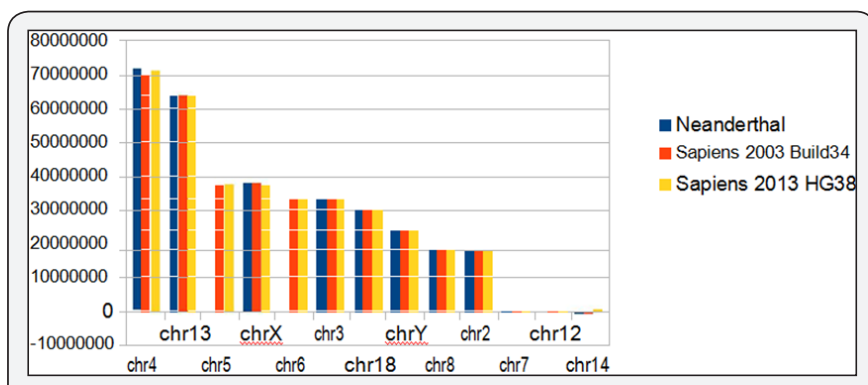

Figure 2: HGO diversity of human chromosomes UPSTREAM of the numerical attractor $\mathrm{HGO}=0.6909830056$.

Detailed values for HGO chromosomes spectral hierarchy for the 3 Human genomes), we have sorted the 24 chromosomes by increasing values of CG/TA ratios in the 3 cases of compared

Table 3: Table of synthesis of $240 \mathrm{LOH}$ relating to 5 types of cancer and 5 different chromosomes. The shaded areas represent those that comply with the HGO law, ie 227 cases out of 240.

\begin{tabular}{|l|l|l|l|l|l|l|l|}
\hline Cancer type & $\begin{array}{l}\text { Chromosome LOH } \\
\text { deletions }\end{array}$ & $\begin{array}{l}\text { LOH } \\
\text { decreasing } \\
\text { (Human } \\
\text { Optimum) }\end{array}$ & $\begin{array}{r}\text { deletions } \\
\text { Genome }\end{array}$ & $\begin{array}{l}\text { LOH } \\
\text { increasing } \\
\text { (Human } \\
\text { Optimum) }\end{array}$ & $\begin{array}{r}\text { deletions } \\
\text { HGO } \\
\text { Genome }\end{array}$ & Total number of LOH & \% law is OK \\
\hline Upstream HGO & Chromosome & 36 & 4 & 40 & \\
\hline Breast & 13 & & & 5 & 42 & \\
\hline Breast & Chromosome & 37 & 5 & & & \\
\hline & 5 & & & & \\
\hline
\end{tabular}

genomes. It then reveals a hierarchical classification scale of 24 chromosomes ranging from 1 / Phi (chromosome4) to 3/2 Phi (chromosome 19) (Figures 1-3).

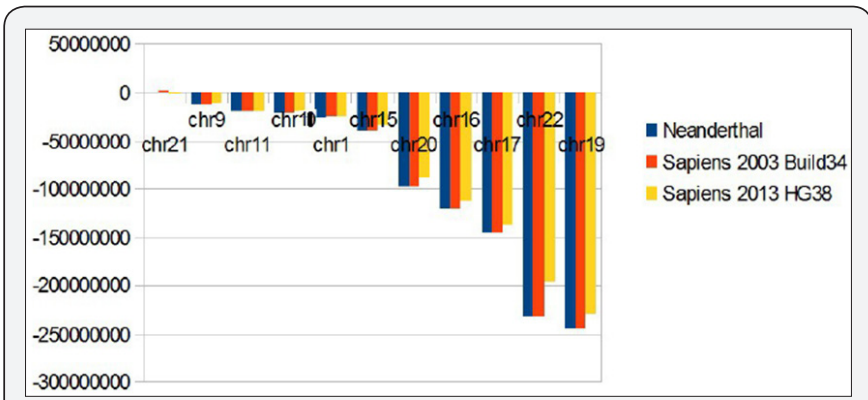

Figure 3 : Diversity of HGOs of human chromosomes DOWNSTREAM of the numerical attractor $\mathrm{HGO}=0.6909830056$.

\section{HGO Disturbed by $240 \mathrm{LOH}$ deletions related to 5 different Chromosomes and 5 different Tumors}

After demonstrating how 3 human genomes with increasing levels of sequencing quality and evolution accuracy seem to "fit" this theoretical value of HGO, we will now analyze how small mutations on one of the chromosomes can "disrupt" this HGO. For this purpose there are a very large number of publications associating such nucleotide regions with deletions of the chromosomal DNA of different tumor cells. We analyzed the Loss of Heterozygosity associated with 240 cases published in [20-25]. These 240 cases relate successively to the Breast [20,21], Glioblastoma [22], Colorectal [23], Neuroblastoma [24], and Prostate [25] cancers. They successively affect the chromosomes 13, 5, 10, 1 and 16.

This exhaustive analysis will then reveal the following generic law:

"When an LOH deletion affects a chromosome upstream of the HGO point (chromosomes 4 13...) in the chromosomal spectrum, this deletion degrades the genomic optimum of the cancer genome. When an LOH deletion affects a chromosome downstream of the HGO point (chromosomes 19 22...) In the chromosomal spectrum, this deletion improves the genomic optimum of the cancer genome. The full details of these analyses are available in « Part 3 - The 240 analyses detailed from 6 independent publications concerning 5 different types of cancer and 5 different chromosomes ». Table 3 below summarizes these results (Table 3 ). 


\section{Cancer Therapy \& Oncology International Journal}

\begin{tabular}{|c|c|c|c|c|c|}
\hline & & & Downstream HGO & & \\
\hline Glioblastoma & Chromosome 10 & 1 & 14 & 15 & \\
\hline Colorectal & Chromosome 1 & 0 & 33 & 33 & \\
\hline Neuroblastoma & Chromosome 1 & 2 & 36 & 38 & \\
\hline \multirow[t]{2}{*}{ Prostate } & Chromosome & 1 & 71 & 72 & \\
\hline & 16 & & & & \\
\hline \multirow[t]{4}{*}{ Total } & & 77 & 163 & 240 & \\
\hline & & LOH deletions & LOH deletions & Total number & $\%$ law is \\
\hline & & respecting the HGO & unrespecting the & of $\mathrm{LOH}$ & $\mathrm{OK}$ \\
\hline & & Law & HGO Law & & \\
\hline Total & & 227 & 13 & 240 & $94.58 \%$ \\
\hline
\end{tabular}

In the Table 1 the shaded areas represent cases of LOH complying with the generic rule, while the unshaded areas represent cases of LOH that do not comply with this rule. In total, 227 cases respect the rule and only 13 cases of $\mathrm{LOH}$ do not respect it, a success rate of this law equal to $94.58 \%$. In «Bold» we represented the 153 Breast and prostate $\mathrm{LOH}$ deletions cases detailed in this article.

\section{Global Graphical Analysis of the 240 LOH Tumor Cases}

In Figure 2 below, the 4 images 2A-2D. below present an overall analysis of the HGOs resulting from the 240 cases of $\mathrm{LOH}$ deletions associated with 5 types of cancers and 5 distinct chromosomes.

For this purpose we recall how to distinguish 3 types of HGO:

The theoretical HGO: (3-Phi) $\div 2=0.6909830055$, where Phi is the $«$ golden ratio $» \mathrm{Phi}=1.618033 \ldots$

The 2 reference HGOs relating to the respective hg38 reference genomes of the female $(0.691347793)$

and man (0.692286423). -The 240 HGOs relating to each of the 240 chromosomes having ubi LOH deletions. On the other hand, the chromosomes are presented in these 4 figures according to the order sequence of the hierarchical spectrum shown in Figure 1.

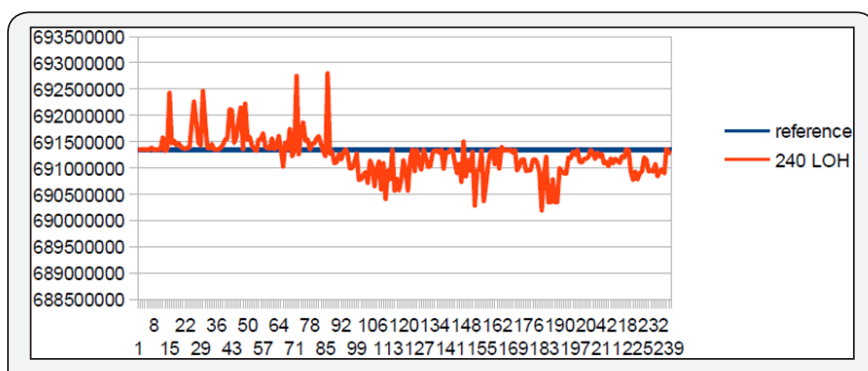

Figure 4 : Case of a woman genome, the 82 on the left are for decreased HGO chromosomes: 1/ at the bottom axis level, the theoretical $\mathrm{HGO}, 2 /$ in blue, the reference woman $\mathrm{HGO}$ value, then, $3 /$ the $240 \mathrm{LOH}$ cases curve: on the left part of the figure LOH HGO values are principally higher than reference woman $\mathrm{HGO}$, on the right part of the figure LOH HGO values are principally lower than reference woman HGO.

Consequently, these 240 cases are presented in the order of upstream towards downstream with respect to the theoretical

HGO. In particular, this is the case for the first $82 \mathrm{LOHs}$ for breast tumors affecting chromosomes13 and 5, both of which are upstream, on the contrary, all remaining LOHs will be downstream (Fig. 1C) of the theoretical HGO point, thus downstream. Thus, Figure 2 will synthesize the relative positions of all these HGOs. Similarly, the errors or distances Figure 2 will also be calculated relative to the respective distances between HGO of the 240 cases of LOH deletions, or of the reference HGOs, with respect to the HGO theoretical (Figures 4-7).

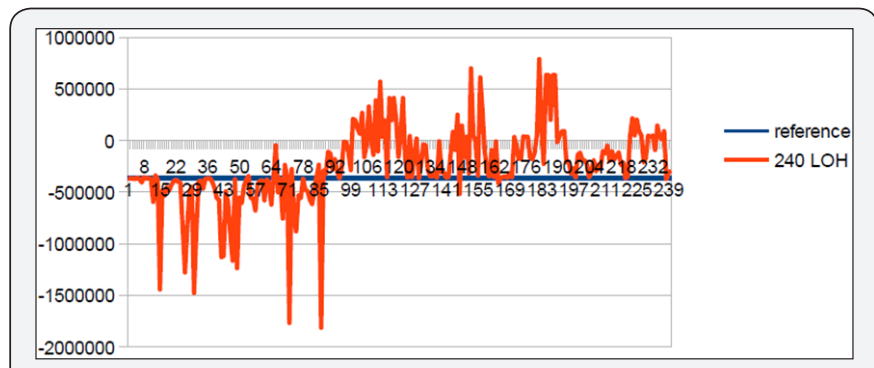

Figure 5 : Case of a woman genome, the 82 on the left are for decreased HGO chromosomes: 1/ at the zero axis level, the theoretical HGO, 2/ in blue, the reference woman HGO error, then, 3 / the $240 \mathrm{LOH}$ cases curve: on the left part of the figure LOH HGO errors are principally higher than reference woman HGO error, on the right part of the figure LOH HGO errors are principally lower than reference woman HGO error.

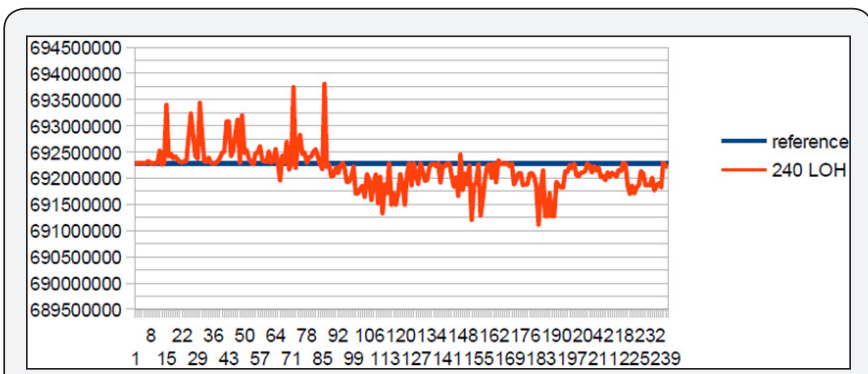

Figure 6 : Case of a man genome, the 82 on the left are for decreased HGO chromosomes: 1/ at the bottom axis level, the theoretical $\mathrm{HGO}, 2 /$ in blue, the reference man $\mathrm{HGO}$ value, then, $3 /$ the $240 \mathrm{LOH}$ cases curve: on the left part of the figure LOH $\mathrm{HGO}$ values are principally higher than reference man $\mathrm{HGO}$, on the right part of the figure LOH HGO values are principally lower than reference man HGO. 


\section{Cancer Therapy \& Oncology International Journal}

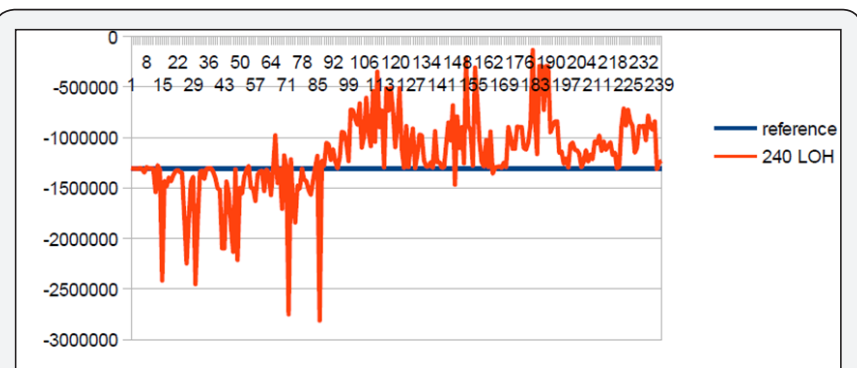

Errors in $\mathrm{HGO}$ man genomes disturbed by $240 \mathrm{LOH}$ the 82 on the left are for $\mathrm{HGO}$ decrease chromosomes

Figure 7 : Case of a man genome, the 82 on the left are for decreased HGO chromosomes: 1/ at the zero axis level, the theoretical HGO, 2/ in blue, the reference man HGO error, then, $3 /$ the $240 \mathrm{LOH}$ cases curve : on the left part of the figure $\mathrm{LOH}$ $\mathrm{HGO}$ errors are principally higher than reference man HGO error, on the right part of the figure LOH HGO errors are principally lower than reference man $\mathrm{HGO}$ error.

\section{Discussion}

We have successively demonstrated that, in the Human Genome Evolution and in the precision of sequencing of the genomes, these genomes seemed to "seek" a sort of numerical optimum: HGO. Then, we demonstrated how the $\mathrm{LOH}$ deletions affecting the tumor cell chromosomes obeyed a generic law based on the chromosome hierarchization illustrated in Figure 1. However, an important open-ended question: do these $\mathrm{LOH}$ deletions affecting the HGO optimum have any potential significance for the pathogenicity and aggressiveness of these tumors? This is what we are going to demonstrate now.

\section{First Analysis: 40 Breast tumors LOH in Chromosome 13}

\section{A. Basic Data}

The article supporting our analysis:

We analyze here $40 \mathrm{LOH}$ associated with Breast cancer of chromosome 13 from the publication:

Eiriksdottir G. et al. [20] Mapping loss of heterozygosity at chromosome 13q: loss at 13q12-q13 is associated with breast tumour progression and poor prognosis, Of the $46 \mathrm{LOH}$ cases published; only 40 cases of exploitable LOH were identified. Indeed some $\mathrm{LOH}$ are reduced to a single marker that is to say approximately $200000 \mathrm{bp}$, which is too insignificant. For example,
Table 11 the first of the markers in this study is D13S1695: chr13: $32,849,425-33,049,658200,234$ bp. However, such a length of $200234 \mathrm{bp}$ is too insignificant.

We therefore retain only the LOHs corresponding to regions delimited by 2 markers (for example the first $\mathrm{LOH}$ referenced 13 in table 11), as well as regions comprising at least 2 markers alone (for example the LOH referenced 3641 comprising 4 Markers alone). The chromosome support of our analysis:

chr13:1-114,364,328 114,364,328 bp

https://genome.ucsc.edu/cgi-bin/s?db=hg38\&lastVirtModeTy pe $=$ default\&lastVirtModeExtraState $=\&$ virtModeType $=$ default $\&$ vir tMode

$=0 \&$ nonVirtPosition $=\&$ position $=$ chr $13 \% 3 \mathrm{~A} 1$ 4328\&hgsid=544158480_4gTu7ZinG6Wue6eggFsvNZ387C0p

The supporting figure of our analysis (Figure 8).

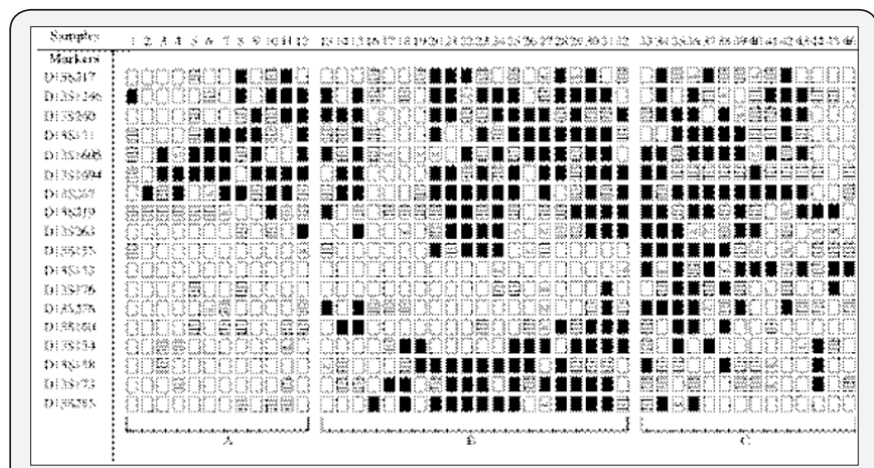

Figure 8 : Deletion mapping of chromosome $13 q$ in 46 breast tumours. Schematic representation of loss of heterozygosity (LOH): solid boxes show LOH, open boxes show retention of heterozygosity and cross-hatched boxes are homozygous for the given marker. nd=not determined. Case numbers are shown at the top. The data were obtained by polymerase chain reaction (PCR) with the markers listed on the left. Tumours in group A are indicative of $\mathrm{LOH}$ at $13 q 12-q 13$, in group $B$ at $13 q 12-q 13$ as well as $13 q 31-q 34$, and in group $C$ the retinoblastoma gene is involved in the tumors, as well as the two regions depicted in groups $A$ and $B$ the case analysed from Figure 1 in publication [20].

B. Basic Results

(Table 4)

Table 4: Detail of 40 Breast tumors LOH deletions of chromosome 13 (The reader will find the complete table11 in the supplementary materials).

\begin{tabular}{|c|c|c|c|c|c|c|c|}
\hline $\begin{array}{c}\text { LOH references : } \\
\text { number / } \\
\text { ref number in published } \\
\text { Figure / Markers Id. }\end{array}$ & $\begin{array}{l}\text { Deleted LOH } \\
\text { regions }\end{array}$ & $\begin{array}{l}\text { Woman } \\
\text { genome XX }\end{array}$ & & & $\begin{array}{l}\text { Man genome } \\
\text { XY }\end{array}$ & & \\
\hline \multirow[t]{3}{*}{$\begin{array}{l}\text { Reference Human Genome } \\
\text { (HG38 2013) }\end{array}$} & & Reference HGO & $\begin{array}{l}\text { Errorideal } \\
\text { HGO - }\end{array}$ & $\mathrm{OK}$ & Reference HGO & $\begin{array}{l}\text { Errorideal } \\
\text { HGO - }\end{array}$ & $\mathrm{OK}$ \\
\hline & & 0.69134779 & reference HGO & & 0.69228642 & $\begin{array}{l}\text { reference } \\
\text { HGO }\end{array}$ & \\
\hline & & & -0.00036478 & & & -0.00130341 & \\
\hline Region A & & & & & & & \\
\hline
\end{tabular}




\section{Cancer Therapy \& Oncology International Journal}

\begin{tabular}{|c|c|c|c|c|c|c|c|c|}
\hline $\begin{array}{cc}1 & 3 \\
\text { D13S1695 } & \text { D13S1694 }\end{array}$ & $\begin{array}{l}32849425 \\
33297510\end{array}$ & & 0.69134714 & -0.00036413 & 1 & 0.69228583 & -0.00130282 & 1 \\
\hline $\begin{array}{c}24 \\
\text { D13S1694 D13S267 }\end{array}$ & $\begin{array}{l}33097286 \\
33790250\end{array}$ & & 0.69135215 & -0.00036915 & 0 & 0.692291 & -0.00130799 & 0 \\
\hline D13S171 $\quad$ D13S1694 & 32579775 & 33297510 & 0.69135118 & -0.00036817 & 0 & 0.69229001 & -0.00130700 & 0 \\
\hline $\begin{array}{c}47 \\
\text { D13S171 D13S267 }\end{array}$ & $\begin{array}{l}32579775 \\
33790250\end{array}$ & & 0.69135563 & -0.00037262 & 0 & 0.69229464 & -0.00131163 & 0 \\
\hline $\begin{array}{c}58 \\
\text { D13S217 D13S1246 } \\
\text { D13S171 } \\
\text { D13S267 }\end{array}$ & $\begin{array}{l}28697654 \\
30631622 \\
32579775 \\
32780083 \\
33589982 \\
33790250\end{array}$ & & 0.69134338 & -0.00036038 & 1 & 0.69228229 & -0.00129929 & 1 \\
\hline $\begin{array}{l}69 \text { D13S260 } \\
\text { D13S1694 }\end{array}$ & 31762621 & 33297510 & 0.69135713 & -0.00037412 & 0 & 0.69229623 & -0.00131323 & 0 \\
\hline $\begin{array}{l}710 \\
\text { D13S1246 } \\
\text { D13S1694 } \\
\text { D13S219 }\end{array}$ & $\begin{array}{l}30431300 \\
30631622 \\
33097286\end{array}$ & 36684592 & 0.69138996 & -0.00040695 & 0 & 0.69233021 & -0.00134721 & 0 \\
\hline $\begin{array}{c}811 \\
\text { D13S217 } \\
\text { D13S260 } \\
\text { D13S1694 } \\
\text { D13S267 }\end{array}$ & $\begin{array}{l}28697654 \\
31962968 \\
33097286 \\
33790250\end{array}$ & & 0.69133825 & -0.00035524 & 1 & 0.6922773 & -0.00129430 & 1 \\
\hline $\begin{array}{c}912 \\
\text { D13S1246 } \\
\text { D13S1694 } \\
\text { D13S263 }\end{array}$ & $\begin{array}{l}30431300 \\
41406784 \\
41607094\end{array}$ & 33297510 & 0.69134803 & -0.00036503 & 0 & 0.69228718 & -0.00130417 & 0 \\
\hline \multicolumn{9}{|l|}{ Region B } \\
\hline $\begin{array}{c}1013 \\
\text { D13S1246 } \\
\text { D13S260 } \\
\text { D13S1695 } \\
\text { D13S219 } \\
\text { D13S276 }\end{array}$ & $\begin{array}{l}30431300 \\
32849425 \\
33049658 \\
36484263 \\
36684592 \\
68335674 \\
68536043 \\
\end{array}$ & 31962968 & 0.69135049 & -0.00036748 & 0 & 0.69228953 & -0.00130653 & 0 \\
\hline $\begin{array}{c}1114 \\
\text { D13S260 } \\
\text { D13S1694 D13S267 D13S160 }\end{array}$ & $\begin{array}{l}31762621 \\
31962968 \\
33097286 \\
33790250 \\
78504466 \\
78704740\end{array}$ & & 0.69135525 & -0.00037225 & 0 & 0.69229424 & -0.00131123 & 0 \\
\hline $\begin{array}{c}1215 \\
\text { D13S1246 } \\
\text { D13S267 } \\
\text { D13S263 }\end{array}$ & $\begin{array}{l}30431300 \\
41406784 \\
41607094 \\
68335674 \\
78704740\end{array}$ & 33790250 & 0.69157604 & -0.00059304 & 0 & 0.6925224 & -0.00153939 & 0 \\
\hline
\end{tabular}

\section{To Conclude}

Recall that chromosome 13 is upstream with respect to the tipping point HGO (manuscript Figure 1). Thus, according to our "global strategy law of LOH by chromosomes", the majority of LOH "should" degrade the value of the HGO: in effect, we observe that 36 out of 40 cases degrade the HGO.

D. Second analysis: 42 Breast tumors $\mathrm{LOH}$ in Chromosome 5

Details in supporting information Table 4.

a. Basic Data
The article supporting our analysis.

In the analysis from Hrefna K. Johannsdottir et al. [21] Chromosome 5 imbalance mapping in breast tumors from BRCA1 and BRCA2 mutation carriers and sporadic breast tumors, Int. J. Cancer: 119, 1052-1060 (2006) ' 2006 Wiley-Liss, Inc, http:// onlinelibrary.wiley.com/doi/10.1002/ijc.21934/pdf

The chromosome support of our analysis:

chr5:1-181,538,259 181,538,259 bp.

https://genome.ucsc.edu/cgi-bin/hgTracks? db=hg 38\&lastVirtModeType=default\&lastVirtModeExtraState 


\section{Cancer Therapy \& Oncology International Journal}

$=\&$ virtModeType $=$ default $\&$ virtMode $=0 \&$ nonVirtPositio $\mathrm{n}=\&$ position $=\operatorname{chr} 5 \% 3 \mathrm{~A} 1-1538259 \& \mathrm{hgsid}=490730839$ uVDpPnDat9B50bik1m1EE017KXGd
The supporting figure of our analysis (Figure 9).

\section{E. Basic Results (Table 5)}

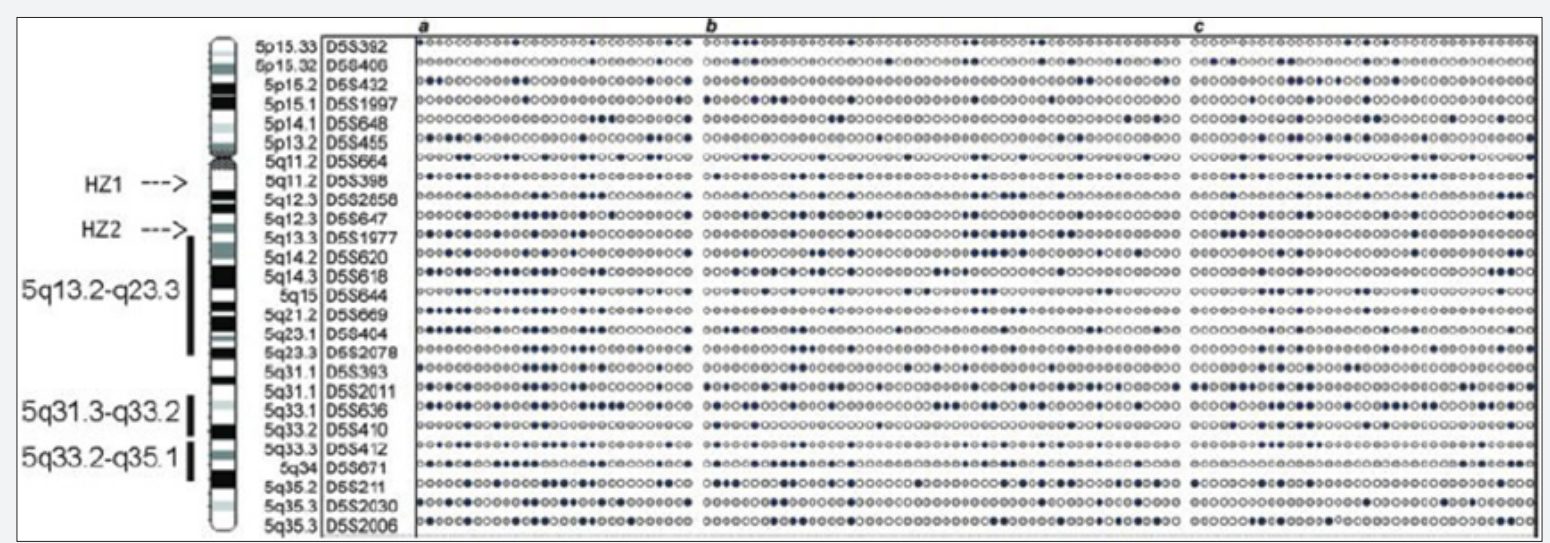

Figure 9 : LOH pattern in breast tumors showing partial and interstitial LOH at chromosome 5 in BRCA1 mutated tumors.

a. BRCA2 mutated tumors;

b. sporadic tumors;

c. $\quad \mathrm{LOH}$ (loss of heterozygosity);

$\mathrm{ROH}$ (retention of heterozygosity); homozygosity or not informative. Tumors showing LOH or retention of heterozygosity at all informative markers are not shown. The chromosome regions showing highest frequencies of deletion in BRCA1 tumors according to the array CGH analysis are marked on the left side. The homozygous deletions ( $\mathrm{HZ1}$ and 2) detected by the array $\mathrm{CGH}$ analysis are indicated with arrows. Indicate an LOH target between markers D5S392 and D5S406 (4.7 Mb) in BRCA1 tumors as well as in BRCA2 and sporadic tumors. Figure 9 - the case analysed from Figure 2 in publication [21].

Table 5: Detail of 42 Breast tumors LOH deletions of chromosome 5 (The reader will find the complete table 12 in the supplementary materials).

\begin{tabular}{|c|c|c|c|c|c|c|c|}
\hline $\begin{array}{c}\text { LOH references : } \\
\text { number / } \\
\text { ref number in }\end{array}$ & $\begin{array}{l}\text { Deleted } \mathrm{LOH} \\
\text { regions }\end{array}$ & \multicolumn{3}{|c|}{ Woman genome $\mathrm{XX}$} & \multicolumn{3}{|c|}{$\begin{array}{c}\text { Man genome } \\
\text { XY }\end{array}$} \\
\hline $\begin{array}{l}\text { Reference Human } \\
\text { Genome (HG38 2013) }\end{array}$ & & $\begin{array}{l}\text { Reference } \\
\text { HGO } \\
0.69134779\end{array}$ & $\begin{array}{c}\text { Error } \\
\text { ideal HGO - } \\
\text { reference HGO } \\
\text {-.00036478 }\end{array}$ & $\mathrm{OK}$ & $\begin{array}{c}\text { Reference } \\
\text { HGO } \\
0.69228642\end{array}$ & $\begin{array}{c}\text { Error } \\
\text { ideal HGO - } \\
\\
\text { reference } \\
\text { HGO } \\
-.00130341\end{array}$ & $\mathrm{OK}$ \\
\hline $\begin{array}{l}\text { BRCA1 Breast tumors } \\
\text { (a) }\end{array}$ & & & & 0 & & & 0 \\
\hline $\begin{array}{c}3 \\
\text { D5S432 } \\
\text { D5S618 } \\
\text { D5S669 D5S404 } \\
\\
\text { D5S636 } \\
\text { D5S412 }\end{array}$ & $\begin{array}{c}10593074 \\
10793430 \\
90370500 \\
90570824 \\
104539362 \\
117611769 \\
\\
150416827 \\
150617121 \\
\\
158675514 \\
158875859\end{array}$ & 0.69155669 & -0.00057368 & 0 & 0.69250257 & -0.00151957 & 0 \\
\hline
\end{tabular}




\section{Cancer Therapy \& Oncology International Journal}

\begin{tabular}{|c|c|c|c|c|c|c|c|}
\hline $\begin{array}{c}5 \\
\text { D1S455 D1S398 } \\
\text { D1S618 D1S404 } \\
\text { D1S636 } \\
\\
\text { D1S412 } \\
6\end{array}$ & $\begin{array}{c}35894219 \\
58373409 \\
90370500 \\
117611769 \\
150416827 \\
150617121 \\
158675514 \\
158875859\end{array}$ & 0.69211454 & -0.00113153 & 0 & 0.69307982 & -0.00209682 & 0 \\
\hline $\begin{array}{c}\mathrm{D} 1 \mathrm{~S} 412 \\
6\end{array}$ & $\begin{array}{c}55577693 \\
150617121\end{array}$ & 0.69210365 & -0.00112064 & 0 & 0.69308176 & -0.00209875 & 0 \\
\hline $\begin{array}{c}\text { D5S664 D5S404 } \\
\text { D5S2011 D5S2006 }\end{array}$ & $\begin{array}{l}141742521 \\
181021853\end{array}$ & & & & & & \\
\hline 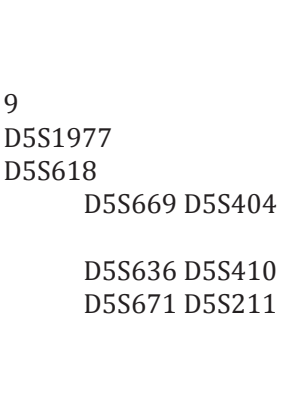 & $\begin{array}{c}76918678 \\
77119014 \\
90370500 \\
90570824 \\
104539362 \\
117611769 \\
\\
158675514 \\
153495801 \\
\\
168195357 \\
173921549\end{array}$ & 0.69147538 & -0.00049238 & 0 & 0.69241936 & -0.00143636 & 0 \\
\hline 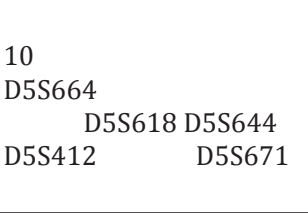 & $\begin{array}{r}55577693 \\
55778017 \\
90370500 \\
96577305 \\
158675514 \\
168395689\end{array}$ & 0.69158353 & -0.00060053 & 0 & 0.69253043 & -0.00154743 & 0 \\
\hline $\begin{array}{l}13 \\
\begin{array}{l}\text { D5S2858 D5S1977 } \\
\text { D5S618 D5S410 }\end{array} \\
\text { D5S671 } \\
\text { D5S2030 D5S2006 }\end{array}$ & $\begin{array}{c}64525211 \\
77119014 \\
90370500 \\
153495801 \\
168195357 \\
168395689 \\
\\
\\
178280172 \\
181021853\end{array}$ & 0.69189479 & -0.00091179 & 0 & 0.69285973 & -0.00187672 & 0 \\
\hline 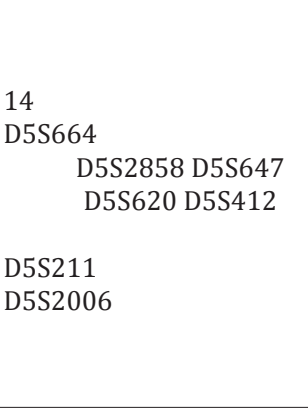 & $\begin{array}{c}55577693 \\
55778017 \\
64525211 \\
67051713 \\
82277212 \\
158875859 \\
\\
141742521 \\
141942802 \\
180821594 \\
181021853\end{array}$ & 0.69214664 & -0.00116364 & 0 & 0.69311486 & -0.00213186 & 0 \\
\hline $\begin{array}{c}17 \\
\text { D5S1977 D5S620 } \\
\text { D5S2078 } \\
\text { D5S2011 } \\
\text { D5S2030 }\end{array}$ & $\begin{array}{r}76918678 \\
82477566 \\
128727878 \\
128928206 \\
173721274 \\
173921549 \\
\\
\\
178280172 \\
178480512\end{array}$ & 0.69136039 & ${ }^{-} 0.00037738$ & 0 & 0.69230034 & -0.00131733 & 0 \\
\hline
\end{tabular}




\section{Cancer Therapy \& Oncology International Journal}

\begin{tabular}{|c|c|c|c|c|c|c|c|}
\hline $\begin{array}{l}18 \\
\text { D5S455 D5S1977 } \\
\text { D5S644 D5S636 } \\
\text { D5S412 } \\
\text { D5S211 } \\
\text { D5S2006 }\end{array}$ & $\begin{array}{r}35894219 \\
96376990 \\
150617121 \\
158675514 \\
158875859 \\
\\
173721274 \\
173921549 \\
\\
180821594 \\
181021853 \\
\end{array}$ & 0.69221927 & -0.00123627 & 0 & 0.69319501 & -0.00221201 & 0 \\
\hline $\begin{array}{c}24 \\
\text { D5S644 D5S669 } \\
\text { D5S2078 }\end{array}$ & $\begin{array}{r}96376990 \\
104739650 \\
128727878 \\
128928206\end{array}$ & 0.69153474 & -0.00055174 & 0 & 0.69247922 & -0.00149622 & 0 \\
\hline $\begin{array}{l}25 \\
\text { D5S432 } \\
\quad \text { D5S455 D5S664 }\end{array}$ & $\begin{array}{c}10593074 \\
10793430 \\
35894219 \\
55778017\end{array}$ & 0.69159059 & -0.00060759 & 0 & 0.69253830 & -0.00155529 & 0 \\
\hline 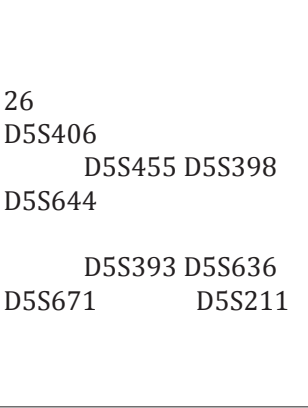 & $\begin{array}{c}4893930 \\
5094254 \\
35894219 \\
58373409 \\
96376990 \\
96577305 \\
\\
136265641 \\
150617121 \\
\\
168195357 \\
173921549\end{array}$ & 0.69142146 & -0.00043846 & 0 & 0.69236897 & -0.00138596 & 0 \\
\hline \multicolumn{8}{|l|}{$\begin{array}{l}\text { BRCA2 breast tumors } \\
\text { (b) }\end{array}$} \\
\hline $\begin{array}{l}\begin{array}{l}2 \\
\text { D5S398 } \\
\text { D5S636 D5S211 }\end{array}\end{array}$ & $\begin{array}{r}58173160 \\
58373409 \\
158675514 \\
173921549\end{array}$ & 0.69137007 & -0.00038707 & 0 & 0.69231178 & -0.00132878 & 0 \\
\hline $\begin{array}{c}\text { 4 D5S392 D5S406 } \\
\text { D5S618 D5S644 } \\
\text { D5S404 } \\
\text { D5S211 }\end{array}$ & $\begin{array}{r}90370500 \\
96577305 \\
117411476 \\
117611769 \\
\\
173721274 \\
173921549\end{array}$ & & & & & & \\
\hline $\begin{array}{l}\text { 11 } \\
\text { D5S398 } \\
\text { D5S647 } \\
\quad \text { D5S404 D5S393 } \\
\quad \text { D5S412 D5S671 } \\
\text { D5S2006 }\end{array}$ & $\begin{array}{c}58173160 \\
58373409 \\
66851322 \\
67051713 \\
173721274 \\
136465819 \\
\\
158675514 \\
168395689 \\
\\
180821594 \\
181021853 \\
\end{array}$ & 0.69154086 & -0.00055785 & 0 & 0.69247962 & -0.00149661 & 0 \\
\hline $\begin{array}{ll}12 & \\
\text { D5S620 } & \text { D5S618 } \\
\text { D5S2078 } & \end{array}$ & $\begin{array}{r}82277212 \\
90570824 \\
128727878 \\
128928206\end{array}$ & 0.69154344 & -0.00056043 & 0 & 0.69248811 & -0.00150511 & 0 \\
\hline
\end{tabular}




\section{Cancer Therapy \& Oncology International Journal}

\begin{tabular}{|c|c|c|c|c|c|c|c|}
\hline $\begin{array}{lc}13 & \\
\text { D5S664 } & \text { D5S647 } \\
\text { D5S620 D5S618 }\end{array}$ & \begin{tabular}{|r|}
55577693 \\
67051713 \\
82277212 \\
90570824 \\
\end{tabular} & 0.69166055 & -0.00067754 & 0 & 0.69260989 & -0.00162689 & 0 \\
\hline $\begin{array}{l}\text { 14 } \\
\text { D5S648 } \\
\text { D5S644 D5S669 } \\
\text { D5S2011 D5S636 } \\
\text { D5S671 } \quad \text { D5S211 }\end{array}$ & $\begin{array}{c}25695625 \\
25895922 \\
96376990 \\
104739650 \\
141742521 \\
158875859 \\
\\
168195357 \\
173921549\end{array}$ & 0.69140625 & -0.00042325 & 0 & 0.69235149 & -0.00136848 & 0 \\
\hline $\begin{array}{l}\text { 15 } \\
\text { D5S1997 } \\
\text { D5S2858 } \\
\quad \text { D5S1977 D5S6218 } \\
\begin{array}{lr}\text { D5S2078 } \\
\text { D5S412 } \quad \text { D5S2006 }\end{array}\end{array}$ & $\begin{array}{c}16882261 \\
17082552 \\
64525211 \\
64725504 \\
76918678 \\
90570824 \\
\\
128727878 \\
128928206 \\
\\
158675514 \\
181021853\end{array}$ & 0.69137649 & -0.00039348 & 0 & 0.69232188 & -0.00133887 & 0 \\
\hline 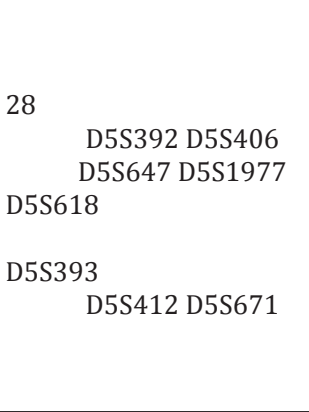 & $\begin{array}{l}202025 \\
5094254 \\
66851322 \\
77119014 \\
90370500 \\
90570824 \\
\\
136265641 \\
136465819 \\
\\
158675514 \\
168395689\end{array}$ & 0.69137200 & -0.00038899 & 0 & 0.69231539 & -0.0013323 & 0 \\
\hline $\begin{array}{lr}29 & \\
\text { D5S392 D5S406 } \\
\text { D5S1997 } \\
\text { D5S664 D5S620 } \\
\text { D5S644 } \quad \text { D5S669 } \\
& \text { D5S2011 }\end{array}$ & $\begin{array}{c}202025 \\
5094254 \\
16882261 \\
17082552 \\
55577693 \\
82477566 \\
\\
96376990 \\
104739650 \\
\\
141742521 \\
141942802\end{array}$ & 0.69156230 & -0.00057929 & 0 & 0.69251279 & -0.00152978 & 0 \\
\hline 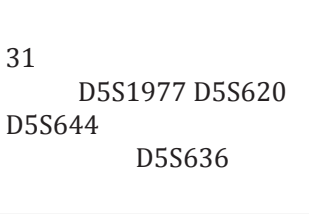 & $\begin{array}{l}76918678 \\
82477566 \\
96376990 \\
96577305 \\
150416827 \\
150617121\end{array}$ & 0.69136130 & -0.00037830 & 0 & 0.69230127 & -0.00131826 & 0 \\
\hline D5S2006 & $\begin{array}{l}180821594 \\
181021853\end{array}$ & & & & & & \\
\hline
\end{tabular}




\section{Cancer Therapy \& Oncology International Journal}

\begin{tabular}{|c|c|c|c|c|c|c|c|}
\hline 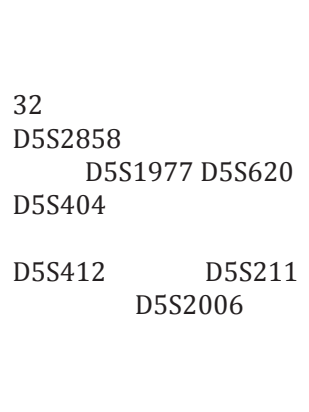 & $\begin{array}{c}64525211 \\
64725504 \\
76918678 \\
82477566 \\
117411476 \\
117611769 \\
\\
158675514 \\
173921549 \\
\\
180821594 \\
181021853\end{array}$ & 0.69139558 & -0.00041257 & 0 & 0.69233889 & -0.00135588 & 0 \\
\hline $\begin{array}{l}36 \text { D5S392 D5S406 } \\
\text { D5S636 } \\
\text { D5S412 D5S2030 }\end{array}$ & \begin{tabular}{|l}
202025 \\
5094254 \\
150416827 \\
150617121 \\
158675514 \\
178480512
\end{tabular} & 0.69160321 & -0.00062020 & 0 & 0.69255168 & -0.00156867 & 0 \\
\hline $\begin{array}{cc} & 40 \\
& \text { D5S432 } \\
\text { D5S455 } & \text { D5S398 } \\
& \text { D5S647 }\end{array}$ & $\begin{array}{l}10593074 \\
10793430 \\
35894219 \\
58373409 \\
66851322 \\
67051713\end{array}$ & 0.69135641 & -0.00037340 & 0 & 0.69230022 & -0.00131721 & 0 \\
\hline 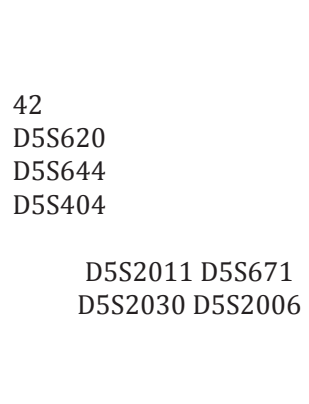 & $\begin{array}{c}82277212 \\
82477566 \\
96376990 \\
96577305 \\
117411476 \\
117611769 \\
\\
141742521 \\
168395689 \\
178280172 \\
181021853\end{array}$ & 0.69102838 & -0.00004537 & 1 & 0.69196161 & -0.00097860 & 1 \\
\hline Sporadic & & & & & & & \\
\hline $\begin{array}{l}\text { 5 } \\
\text { D5S406 } \\
\quad \text { D5S398 D5S1977 } \\
\text { D5S2011 D5S410 }\end{array}$ & $\begin{array}{c}4893930 \\
5094254 \\
58173160 \\
77119014 \\
141742521 \\
153495801\end{array}$ & 0.69148573 & -0.00050272 & 0 & 0.69243277 & -0.00144976 & 0 \\
\hline \begin{tabular}{l}
6 \\
D5S648 \\
D5S664 D5S398 \\
D5S1977 \\
\multicolumn{1}{c}{ D5S2011 }
\end{tabular} & $\begin{array}{l}25695625 \\
25895922 \\
55577693 \\
58373409 \\
76918678 \\
77119014 \\
\\
141742521 \\
141942802\end{array}$ & 0.69135535 & -0.00037235 & 0 & 0.69229472 & -0.00131172 & 0 \\
\hline $\begin{array}{c}9 \\
\text { D5S644 D5S404 } \\
\text { D5S636 } \\
\text { D5S412 }\end{array}$ & \begin{tabular}{|l}
96376990 \\
117611769 \\
150416827 \\
150617121 \\
158675514 \\
158875859
\end{tabular} & 0.69173687 & -0.00075387 & 0 & 0.69268834 & -0.00170534 & 0 \\
\hline
\end{tabular}




\section{Cancer Therapy \& Oncology International Journal}

\begin{tabular}{|c|c|c|c|c|c|c|c|}
\hline $\begin{array}{l}10 \\
\text { D5S620 } \\
\text { D5S644 } \\
\qquad 55 S 2078 \text { D5S412 } \\
\qquad \text { D5S211 } \\
\quad \text { D5S2006 }\end{array}$ & $\begin{array}{c}82277212 \\
82477566 \\
96376990 \\
96577305 \\
128727878 \\
158875859 \\
\\
173721274 \\
173921549 \\
\\
180821594 \\
181021853\end{array}$ & 0.69121921 & -0.00023620 & 1 & 0.69215990 & -0.00117690 & 1 \\
\hline $\begin{array}{lr}11 & \\
\text { D5S406 } & \text { D5S432 } \\
& \text { D5S455 }\end{array}$ & $\begin{array}{l}4893930 \\
10793430 \\
35894219 \\
36094418\end{array}$ & 0.69132699 & -0.00034399 & 1 & 0.69226614 & -0.00128313 & 1 \\
\hline 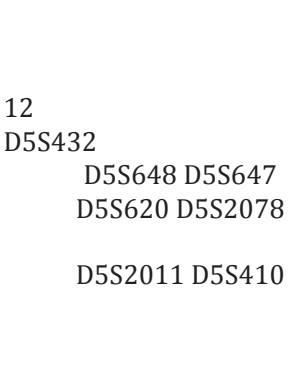 & $\begin{array}{c}10593074 \\
10793430 \\
25695625 \\
67051713 \\
82277212 \\
128928206 \\
\\
\\
173721274 \\
153495801\end{array}$ & 0.69275045 & -0.00176744 & 0 & 0.69373407 & -0.00275107 & 0 \\
\hline 13 & $\begin{array}{l}58173160 \\
58373409\end{array}$ & 0.69125826 & -0.00027525 & 1 & 0.69219863 & -0.00121563 & 1 \\
\hline D5S398 & $\begin{array}{l}66851322 \\
67051713\end{array}$ & & & & & & \\
\hline D5S647 & $\begin{array}{l}96376990 \\
96577305 \\
\end{array}$ & & & & & & \\
\hline \multicolumn{8}{|l|}{ D5S644 } \\
\hline & $\begin{array}{l}136265641 \\
158875859\end{array}$ & & & & & & \\
\hline $\begin{array}{c}\text { D5S393 D5S412 } \\
\text { D5S211 }\end{array}$ & $\begin{array}{l}173721274 \\
173921549\end{array}$ & & & & & & \\
\hline $\begin{array}{c}15 \text { D5S455 D5S2858 } \\
\text { D5S2006 }\end{array}$ & $\begin{array}{r}35894219 \\
64725504 \\
180821594 \\
181021853\end{array}$ & 0.69168749 & -0.00070448 & 0 & 0.69263900 & -0.00165600 & 0 \\
\hline $\begin{array}{l}19 \\
\text { D5S392 D5S455 } \\
\text { D5S398 D5S2858 } \\
\text { D5S644 D5S669 } \\
\text { D5S410 } \\
\text { D5S2030 }\end{array}$ & $\begin{array}{l}202025 \\
36094418 \\
58173160 \\
64725504 \\
96376990 \\
104739650 \\
\\
153295415 \\
153495801 \\
\\
178280172 \\
178480512\end{array}$ & 0.69186327 & -0.00088027 & 0 & 0.69282275 & -0.00183974 & 0 \\
\hline
\end{tabular}




\section{Cancer Therapy \& Oncology International Journal}

\begin{tabular}{|c|c|c|c|c|c|c|c|}
\hline $\begin{array}{c}21 \\
\text { D5S392 } \\
\text { D5S398 } \\
\text { D5S647 } \\
\text { D5S404 D5S2078 } \\
\text { D5S636 D5S410 }\end{array}$ & $\begin{array}{c}202025402151 \\
58173160 \\
58373409 \\
66851322 \\
67051713 \\
\\
117411476 \\
128928206 \\
\\
150416827 \\
153495801\end{array}$ & 0.69151381 & -0.00053081 & 0 & 0.6924589 & -0.00147589 & 0 \\
\hline \begin{tabular}{l}
24 \\
D5S664 D5S620 \\
D5S644 \\
\multicolumn{1}{c}{ D5S404 }
\end{tabular} & $\begin{array}{r}55577693 \\
82477566 \\
96376990 \\
96577305 \\
117411476 \\
117611769\end{array}$ & 0.69154041 & -0.00055740 & 0 & 0.69248815 & -0.00150515 & 0 \\
\hline $\begin{array}{c}26 \\
\text { D5S664 D5S398 } \\
\text { D5S2078 } \\
\text { D5S636 }\end{array}$ & $\begin{array}{c}55577693 \\
58373409 \\
128727878 \\
128928206 \\
150416827 \\
150617121\end{array}$ & 0.69135403 & -0.00037102 & 0 & 0.69229333 & -0.00131033 & 0 \\
\hline $\begin{array}{l}31 \\
\text { D5S636 } \\
\quad \text { D5S412 D5S671 }\end{array}$ & $\begin{array}{l}150416827 \\
150617121 \\
158675514 \\
168395689\end{array}$ & 0.69145662 & -0.00047361 & 0 & 0.69239947 & -0.00141646 & 0 \\
\hline 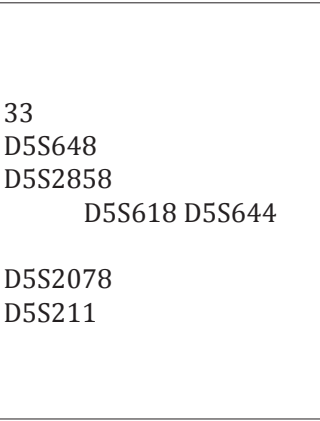 & $\begin{array}{c}25695625 \\
25895922 \\
64525211 \\
64725504 \\
90370500 \\
96577305 \\
\\
128727878 \\
128928206 \\
173721274 \\
173921549\end{array}$ & 0.69147158 & -0.00048858 & 0 & 0.69241431 & -0.00143130 & 0 \\
\hline $\begin{array}{l}\text { D5S2858 D5S647 } \\
\text { D5S620 D5S618 } \\
\text { D5S404 } \\
\text { D5S2011 D5S410 } \\
\text { D5S671 }\end{array}$ & $\begin{array}{c}64525211 \\
67051713 \\
82277212 \\
90570824 \\
117411476 \\
117611769 \\
\\
141742521 \\
153495801 \\
168195357 \\
168395689\end{array}$ & 0.69155438 & -0.00057137 & 0 & 0.69250173 & -0.00151872 & 0 \\
\hline $\begin{array}{lr}36 & \\
\text { D5S455 } & \text { D5S398 } \\
\text { D5S2078 } & \\
& \text { D5S2011 }\end{array}$ & $\begin{array}{c}35894219 \\
58373409 \\
128727878 \\
128928206 \\
141742521 \\
141942802\end{array}$ & 0.69160183 & -0.00061883 & 0 & 0.69255027 & -0.00156727 & 0 \\
\hline $\begin{array}{l}\text { Total LOH which are } \\
\text { OK with the HGO Law } \\
\text { (then 0) }\end{array}$ & & & & $\begin{array}{l}37 \\
\text { by } \\
42\end{array}$ & & & $\begin{array}{l}37 \\
\text { by } \\
42\end{array}$ \\
\hline
\end{tabular}




\section{a. To Conclude}

Recall that chromosome 5 is upstream with respect to the tipping point HGO (see manuscript Figure 1).. Therefore, by virtue of our "global strategy law for LOH by chromosomes", most LOHs "should" degrade the HGO value: in effect, 37 out of 42 cases degrade HGO.

b. Third analysis: 72 Prostate tumors $\mathrm{LOH}$ in Chromosome 16:

Details in supporting information Figures 5 \& 6 .

\section{F. Basic Data}

The article supporting our analysis:

Latil A. et al. [25] Loss of heterozygosity at chromosome $16 \mathrm{q}$ in prostate adenocarcinoma: identification of three independent regions. , http://cancerres.aacrjournals.org/content/57/6/1058. long.

The chromosome support of our analysis: chr16:1-90,338,345 90,338,345 bp.

https://genome.ucsc.edu/cgi-bin/s?db=hg38\&lastVirtModeTy pe $=$ default\&lastVirtModeExtraState $=\&$ virtModeType $=$ default $\&$ vir tMode

$=0$ \&nonVirtPosition $=\&$ position $=\operatorname{chr} 16 \% 3 \mathrm{~A} 1-$

903383445 \& h g s i d = 5122328625 . KTg3NgwGLbBBObaQAQwxFiLtKd10

The supporting figure of our analysis (Figure 10).

a. Basic Results (Table 6)

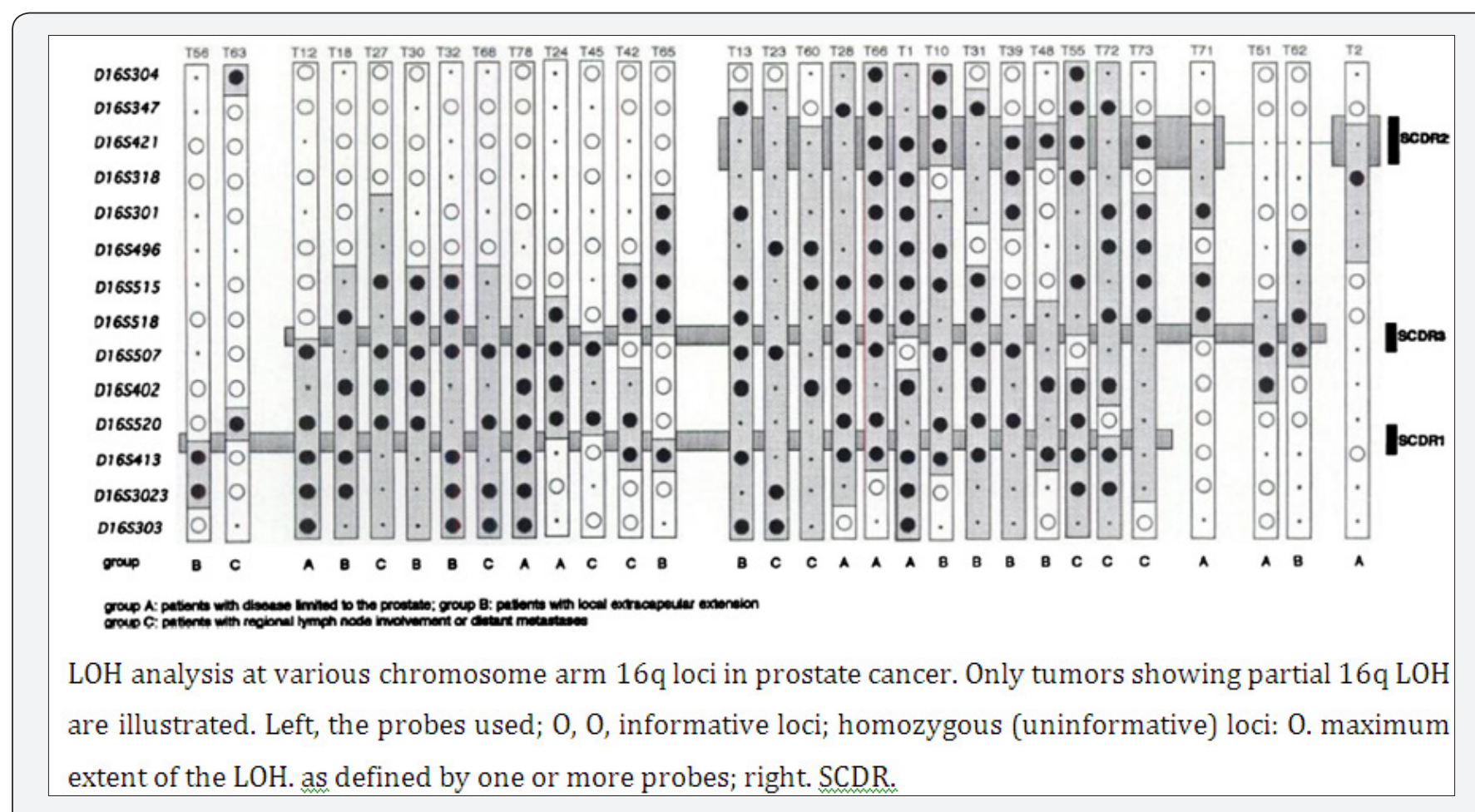

Figure 10 :The case analysed from Figure 1 in publication [25].

Table 6: Detail of 72 Prostate tumors LOH deletions of chromosome 16 (The reader will find the complete table 16 in the supplementary materials).

\begin{tabular}{|c|c|c|c|c|c|c|c|}
\hline \multirow{2}{*}{$\begin{array}{l}\text { LOH references : } \\
\text { number / } \\
\text { ref number in published } \\
\text { figure / Markers Id. } \\
\\
\text { Reference Human } \\
\text { Genome (HG38 2013) }\end{array}$} & \multirow[t]{2}{*}{ Deleted LOH regions } & \multicolumn{3}{|c|}{ Woman genome $\mathrm{XX}$} & \multicolumn{3}{|c|}{$\begin{array}{c}\text { Man genome } \\
\text { XY }\end{array}$} \\
\hline & & $\begin{array}{c}\text { Reference } \\
\text { HGO } \\
0.69134779\end{array}$ & $\begin{array}{c}\text { Error } \\
\text { ideal HGO - } \\
\\
\text { reference } \\
\text { HGO } \\
-.00036478\end{array}$ & $\mathrm{OK}$ & $\begin{array}{c}\text { Reference } \\
\text { HGO } \\
0.69228642\end{array}$ & $\begin{array}{c}\text { Error } \\
\text { ideal HGO - } \\
\text { reference HGO } \\
\text {-.00130341 }\end{array}$ & $\mathrm{OK}$ \\
\hline
\end{tabular}




\section{Cancer Therapy \& Oncology International Journal}

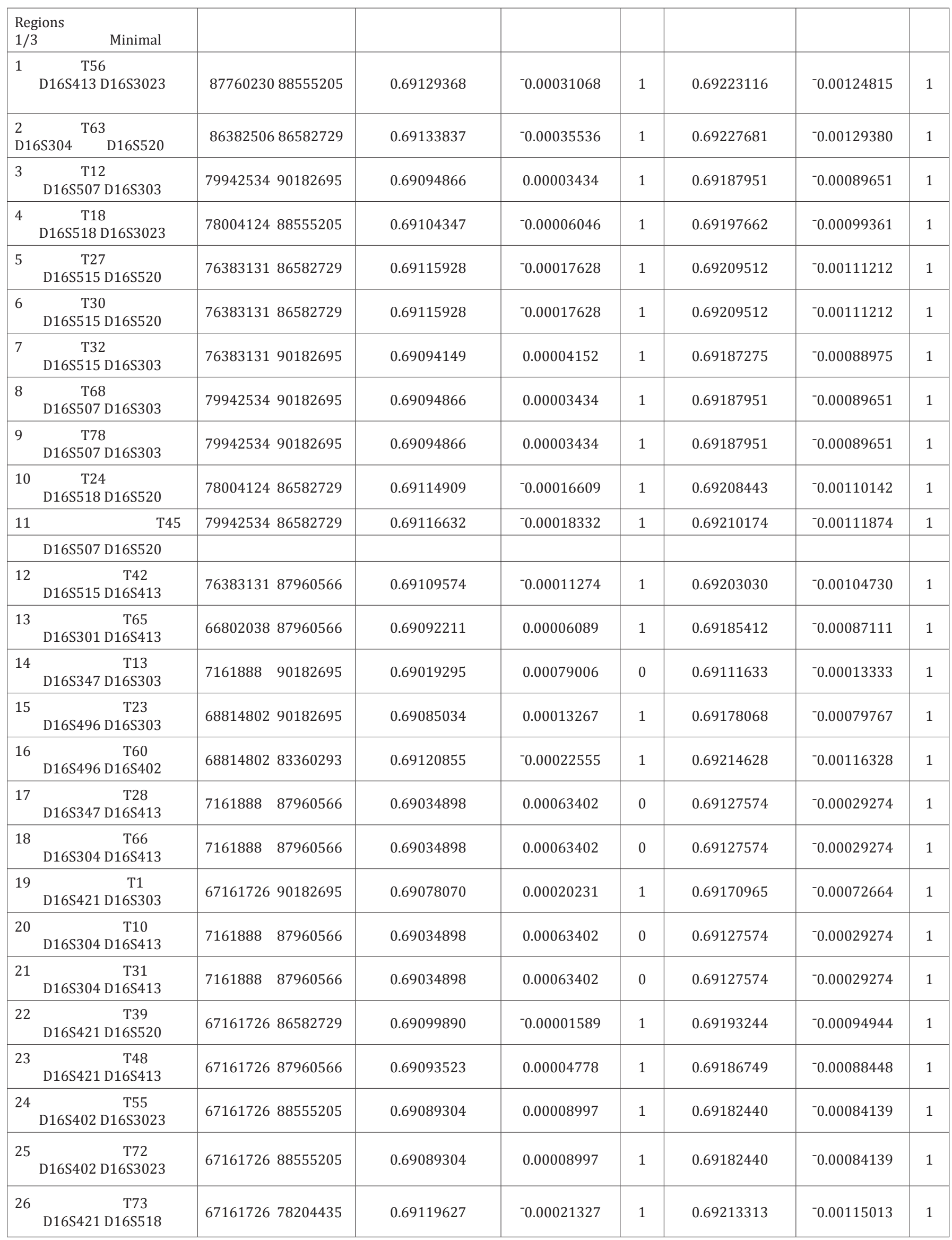




\section{Cancer Therapy \& Oncology International Journal}

\begin{tabular}{|c|c|c|c|c|c|c|c|c|}
\hline \multicolumn{2}{|c|}{$\begin{array}{cc}27 & \text { T71 } \\
& \text { D16S301 D16S518 } \\
\end{array}$} & 6680203878204435 & 0.69118319 & -0.00020019 & 1 & 0.69211980 & -0.00113679 & 1 \\
\hline \multicolumn{2}{|c|}{$\begin{array}{c}\text { T51 } \\
\text { D16S507 D16S402 }\end{array}$} & 7994253483360293 & 0.69130612 & -0.00032311 & 1 & 0.69224433 & -0.00126132 & 1 \\
\hline \multicolumn{2}{|c|}{$\begin{array}{c}\text { T62 } \\
\text { D16S496 D16S507 }\end{array}$} & 6881480280142885 & 0.69125013 & -0.00026713 & 1 & 0.69218832 & -0.00120531 & 1 \\
\hline 30 & $\mathrm{~T} 2$ & 6716188867362019 & 0.69133725 & -0.00035425 & 1 & 0.69227567 & -0.00129266 & 1 \\
\hline \multicolumn{2}{|l|}{ D16S318 } & & & & & & & \\
\hline \multicolumn{2}{|c|}{ 2/3 Regions } & & & & & & & \\
\hline \multicolumn{2}{|c|}{$\begin{array}{l}31 \mathrm{~T} 12 \\
\mathrm{D} 16 \mathrm{~S} 507 \\
\text { D16S520 D16S303 }\end{array}$} & $\begin{array}{r}7994253480142885 \\
8638250690182695\end{array}$ & 0.69112078 & -0.00013778 & 1 & 0.69205469 & -0.00107169 & 1 \\
\hline \multicolumn{2}{|c|}{$\begin{array}{l}32 \\
\mathrm{D} 16 \mathrm{~T} 518\end{array}$} & $\begin{array}{r}7800412478204435 \\
8315980988555205\end{array}$ & 0.69110000 & -0.00011699 & 1 & 0.69203368 & -0.00105067 & 1 \\
\hline $\begin{array}{l}33 \mathrm{~T} 27 \\
\text { D16S515 } \\
\text { D16S507 }\end{array}$ & D16S520 & $\begin{array}{r}7638313176583505 \\
7994253486582729\end{array}$ & 0.69117068 & -0.00018767 & 1 & 0.69210623 & -0.00112323 & 1 \\
\hline $\begin{array}{l}34 \text { T32 } \\
\text { D16S515 }\end{array}$ & $\begin{array}{l}\text { D16S507 } \\
\text { D16S303 }\end{array}$ & $\begin{array}{l}7638313180142885 \\
8776023090182695\end{array}$ & 0.69117454 & -0.00019154 & 1 & 0.69211008 & -0.00112708 & 1 \\
\hline $\begin{array}{l}35 \mathrm{~T} 68 \\
\text { D16S507 } \\
\text { D16S520 } \\
\text { D16S3023 } \\
\end{array}$ & D16S303 & $\begin{array}{r}7994253480142885 \\
8638250686582729 \\
8835491990182695\end{array}$ & 0.69120697 & -0.00022396 & 1 & 0.69214262 & -0.00115962 & 1 \\
\hline \multicolumn{2}{|c|}{$\begin{array}{c}36 \mathrm{~T} 45 \\
\mathrm{D} 16 \mathrm{~S} 507\end{array}$} & $\begin{array}{l}7994253480142885 \\
8638250686582729\end{array}$ & 0.69133815 & -0.00035514 & 1 & 0.69227661 & -0.00129361 & 1 \\
\hline \multicolumn{2}{|c|}{$\begin{array}{l}37 \text { T42 } \\
\text { D16S515 D16S518 } \\
\text { D16S520 D16S413 }\end{array}$} & $\begin{array}{l}7638313178204435 \\
8638250687960566\end{array}$ & 0.69128331 & -0.00030030 & 1 & 0.69222097 & -0.00123796 & 1 \\
\hline \multirow[t]{2}{*}{38} & $\begin{array}{l}\mathrm{T} 65 \\
6 \mathrm{~S} 301 \\
\mathrm{SS} 413 \\
\end{array}$ & $\begin{array}{r}6680203878204435 \\
8776023087960566\end{array}$ & 0.69117107 & -0.00018806 & 1 & 0.69210742 & -0.00112442 & 1 \\
\hline & $\begin{array}{c}\mathrm{T} 13 \\
\text { 6S421 } \\
\text { 6S301 } \\
\text { 6S515 } \\
\text { 6S413 } \\
\text { 6S303 }\end{array}$ & $\begin{array}{r}6716172667362083 \\
6680203867002181 \\
7638313183360293 \\
8776023087960566 \\
8998259090182695\end{array}$ & 0.69128322 & -0.00030022 & 1 & 0.69222151 & -0.00123851 & 1 \\
\hline $\begin{array}{l}40 \quad T \\
\text { D16S 496 } \\
\text { D16S507 } \\
\text { D16S3023 }\end{array}$ & D16S303 & $\begin{array}{r}6881480269015161 \\
7994253480142885 \\
8835491990182695\end{array}$ & 0.69121462 & -0.00023162 & 1 & 0.69215046 & -0.00116746 & 1 \\
\hline & $\mathrm{T} 60$ & $\begin{array}{r}6881480276583505 \\
8315980983360293\end{array}$ & 0.69126101 & -0.00027800 & 1 & 0.69219890 & -0.00121589 & 1 \\
\hline
\end{tabular}




\section{Cancer Therapy \& Oncology International Journal}

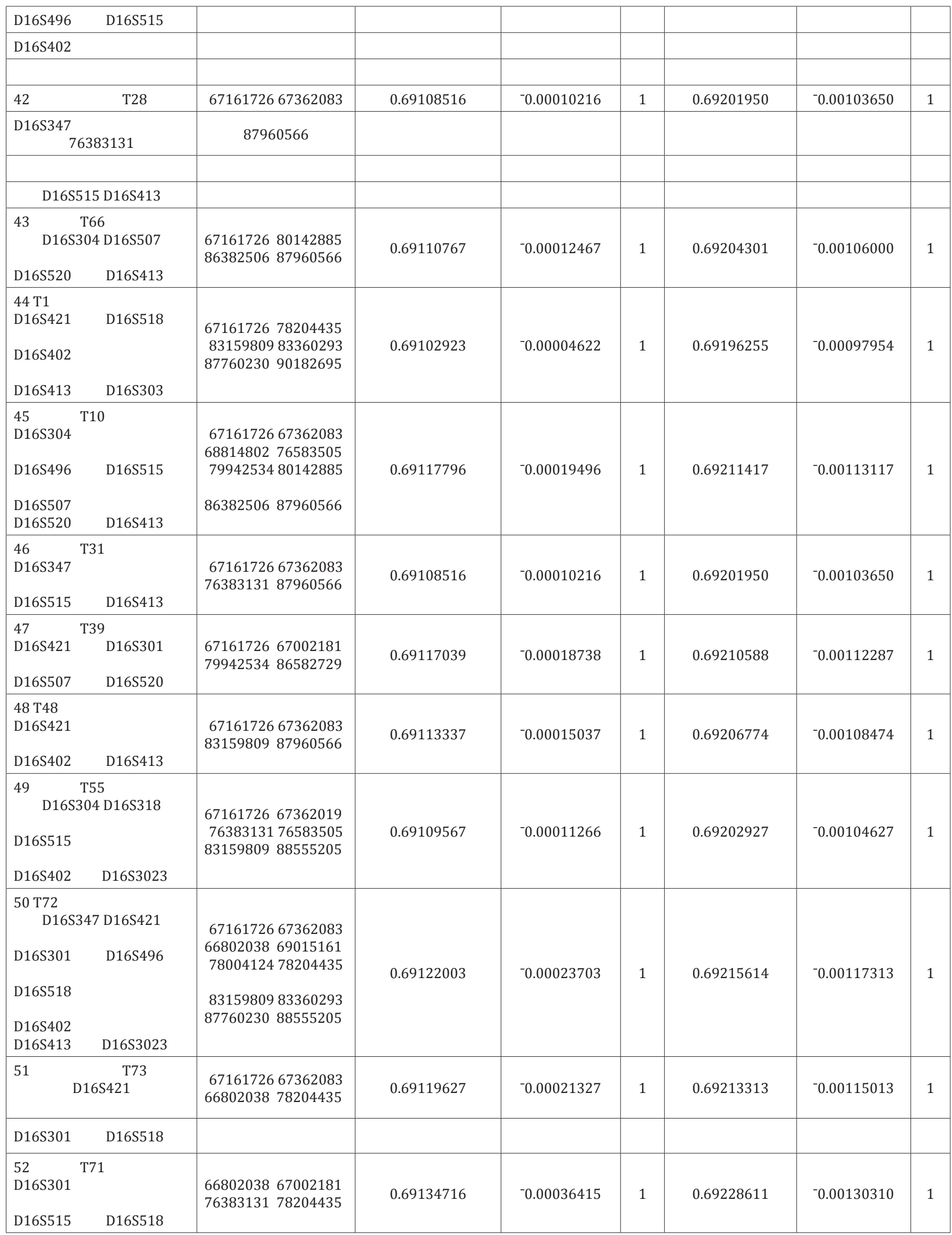




\section{Cancer Therapy \& Oncology International Journal}

\begin{tabular}{|c|c|c|c|c|c|c|c|}
\hline $\begin{array}{lr}53 & \text { T62 } \\
\text { D16S496 } & \\
\text { D16S518 } & \text { D16S507 }\end{array}$ & $\begin{array}{r}6881480269015161 \\
7800412480142885\end{array}$ & 0.69132865 & -0.00034564 & 1 & 0.69226721 & -0.00128421 & 1 \\
\hline $\begin{array}{l}\text { Regions } \\
\qquad 3 / 3 \text { Maximal }\end{array}$ & & & & 1 & & & 1 \\
\hline $\begin{array}{lr}54 & \text { T18 } \\
\text { D16S515 } & \text { D16S303 }\end{array}$ & 7638313190182695 & 0.69094149 & 0.00004152 & 1 & 0.69187275 & -0.00088975 & 1 \\
\hline $\begin{array}{lr}55 & \text { T27 } \\
\text { D16S301 } & \text { D16S303 }\end{array}$ & 6680203890182695 & 0.69076757 & 0.00021544 & 1 & 0.69169627 & -0.00071326 & 1 \\
\hline $\begin{array}{lr}56 & \text { T78 } \\
\text { D16S518 } & \text { D16S303 }\end{array}$ & 7800412490182695 & 0.69093136 & 0.00005165 & 1 & 0.69186211 & -0.00087911 & 1 \\
\hline $\begin{array}{lr}57 & \text { T23 } \\
\text { D16S347 } & \text { D16S303 }\end{array}$ & 6716172690182695 & 0.69078070 & 0.00020231 & 1 & 0.69170965 & -0.00072664 & 1 \\
\hline $\begin{array}{cc}58 & \text { T28 } \\
& \text { D16S421 D16S3023 } \\
\end{array}$ & 6716172688555205 & 0.69089304 & 0.00008997 & 1 & 0.69182440 & -0.00084139 & 1 \\
\hline $\begin{array}{cc}59 & \text { T66 } \\
& \text { D16S421 D16S413 }\end{array}$ & 6716172687960566 & 0.69093523 & 0.00004778 & 1 & 0.69186749 & -0.00088448 & 1 \\
\hline $\begin{array}{lr}60 & \text { T71 } \\
\text { D16S421 } & \text { D16S518 }\end{array}$ & 6716172678204435 & 0.69119627 & -0.00021327 & 1 & 0.69213313 & -0.00115013 & 1 \\
\hline $\begin{array}{l}\text { Autres multiples } \\
\text { maximums }\end{array}$ & & & & & & & \\
\hline $\begin{array}{lr}61 & \text { T42 } \\
\text { D16S515 } & \text { D16S518 } \\
& \\
\text { D16S402 } & \text { D16S413 }\end{array}$ & $\begin{array}{l}7638313178204435 \\
8315980987960566\end{array}$ & 0.69115224 & -0.00016924 & 1 & 0.69208733 & -0.00110432 & 1 \\
\hline $\begin{array}{lr}62 & \text { T10 } \\
\text { D16S421 } & \\
\text { D16S301 } & \text { D16S413 }\end{array}$ & $\begin{array}{r}6716172667362083 \\
6680203887960566\end{array}$ & 0.69093523 & 0.00004778 & 1 & 0.69186749 & -0.00088448 & 1 \\
\hline $\begin{array}{lr}63 & \text { T31 } \\
\text { D16S421 } & \text { D16S301 } \\
& \\
\text { D16S515 } & \text { D16S303 }\end{array}$ & $\begin{array}{l}6716172667002181 \\
7638313190182695\end{array}$ & 0.69094556 & 0.00003744 & 1 & 0.69187690 & -0.00089389 & 1 \\
\hline $\begin{array}{lr}64 & \text { T39 } \\
\text { D16S421 } & \text { D16S301 } \\
& \\
\text { D16S518 } & \text { D16S303 }\end{array}$ & $\begin{array}{l}6716172667002181 \\
7800412490182695\end{array}$ & 0.69093543 & 0.00004757 & 1 & 0.69186626 & -0.00088325 & 1 \\
\hline $\begin{array}{lr}65 & \mathrm{~T} 48 \\
& \mathrm{D} 16 \mathrm{~S} 421\end{array}$ & $\begin{array}{r}6716172667362083 \\
7800412487960566\end{array}$ & 0.69107499 & -0.00009199 & 1 & 0.69200883 & -0.00102582 & 1 \\
\hline D16S518 D16S413 & & & & & & & \\
\hline $\begin{array}{lll}66 & \mathrm{~T} 1 & \\
\mathrm{D} 16 \mathrm{~S} 421 & \mathrm{D} 16 \mathrm{~S} 518 \\
& & \\
\mathrm{D} 16 \mathrm{~S} 402 & \mathrm{D} 16 \mathrm{~S} 303\end{array}$ & $\begin{array}{l}6716172678204435 \\
8315980990182695\end{array}$ & 0.69083756 & 0.00014545 & 1 & 0.69176705 & -0.00078404 & 1 \\
\hline $\begin{array}{lr}67 & \text { T10 } \\
\text { D16S421 } & \\
\text { D16S301 } & \text { D16S413 }\end{array}$ & $\begin{array}{r}6716172667362083 \\
6680203887960566\end{array}$ & 0.69093523 & 0.00004778 & 1 & 0.69186749 & -0.00088448 & 1 \\
\hline $\begin{array}{lr}68 & \text { T72 } \\
\text { D16S421 } & \text { D16S402 } \\
& \\
\text { D16S413 } & \text { D16S303 }\end{array}$ & $\begin{array}{l}67161726 \\
83360293 \\
8776023090182695\end{array}$ & 0.69097256 & 0.00001045 & 1 & 0.69190535 & -0.00092234 & 1 \\
\hline $\begin{array}{lr}69 & \text { T73 } \\
\text { D16S421 } & \\
\text { D16S301 } & \text { D16S3023 }\end{array}$ & $\begin{array}{r}6716172667362083 \\
6680203888555205\end{array}$ & 0.69089304 & 0.00008997 & 1 & 0.69182440 & -0.00084139 & 1 \\
\hline
\end{tabular}




\section{Cancer Therapy \& Oncology International Journal}

\begin{tabular}{|c|c|c|c|c|c|c|c|c|}
\hline $\begin{array}{l}70 \\
\text { D16S421 } \\
\text { D16S515 }\end{array}$ & $\begin{array}{l}71 \\
\text { D16S301 } \\
\text { D16S518 }\end{array}$ & $\begin{array}{r}6700218167161726 \\
7638313178204435\end{array}$ & 0.69135616 & -0.00037315 & 0 & 0.69229529 & -0.00131228 & 0 \\
\hline $\begin{array}{l}71 \\
\text { D16S518 }\end{array}$ & $\mathrm{T} 51$ & 7800412483360293 & 0.69128895 & -0.00030594 & 1 & 0.69222706 & -0.00124406 & 1 \\
\hline $\begin{array}{l}72 \\
\mathrm{D} 16 S 421\end{array}$ & $21^{\mathrm{T} 2} \mathrm{D} 16 \mathrm{~S} 496$ & 6716172669015161 & 0.69127674 & -0.00029373 & 1 & 0.69221399 & -0.00123098 & 1 \\
\hline \multicolumn{2}{|c|}{$\begin{array}{l}\text { Total LOH which are OK } \\
\text { with the HGO Law (then } \\
\text { 1) }\end{array}$} & & & & $\begin{array}{l}66 \\
\text { by } \\
72\end{array}$ & & & $\begin{array}{l}71 \\
\text { by } \\
72\end{array}$ \\
\hline
\end{tabular}

\section{i. To Conclude}

Recall that chromosome 16 is downstream with respect to the tipping point HGO (see manuscript Figure 1). Therefore, by virtue of our "global LOH strategy law by chromosomes", most LOHs "should" improve the HGO value: in fact, 66 cases out of 72 increase the HGO in the case of a Genome (XX) but 71 out of 72 cases increase HGO in the case of a male genome (XY).

\section{Discussion}

\section{First analysis: 40 Breast tumors LOH in Chromosome} 13:

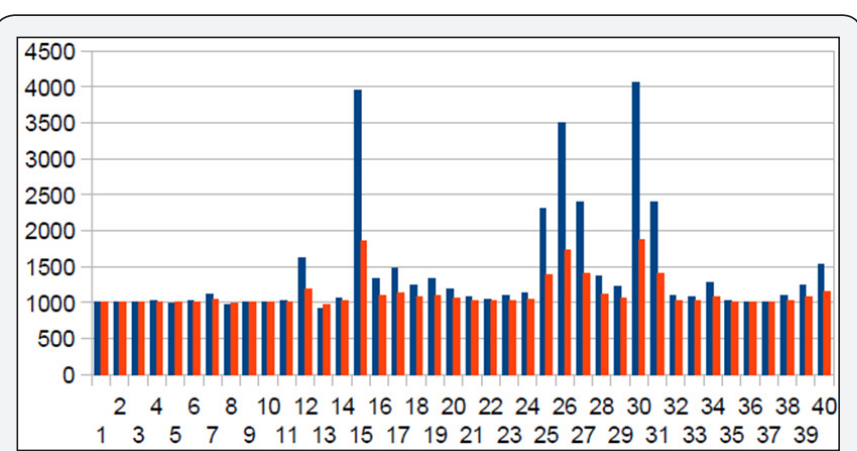

Figure 11 : Effect of LOH of chromosome 13 on HGO ratio in breast cancers on the same genome according to whether it is female $(\mathrm{XX})$ or male $(\mathrm{XY})$. Ratio decreasing $\mathrm{HGO}$ female/male $=1.27$.

(Figure 10) Effect of LOH of chromosome 13 on HGO ratio in breast cancers on the same genome according to whether it is female $(X X)$ or male $(X Y)$. Ratio decreasing HGO female $/$ male $=1.27$. In the analysis from publication (20), we show that HGO conforms to the above law in 36 of 40 cases (chromosome 13 is in the region upstream of the HGO point, Figure 1). In Figure 10, it is interesting to note that the effect on a female genome $(\mathrm{XX})$ is greater than the effect on this same male genome (XY), which is in agreement with the fact that this cancer is almost exclusively feminine. A rapid analysis of the degradations of HGO - for the same LOH - depending on whether the genome is XY (masculine) or XX (feminine), will show that these expected degradations are 1.27 times higher in the case of a female genome (XX). This would reinforce the fact that the female genome is more sensitive to these $\mathrm{LOH}$ deletions than the male genome (Figure 11).
II. Second Analysis: 42 Breast tumors LOH in Chromosome 5:

In the analysis from publication [21], we show (Figure 3) that the HGO conforms to the above-mentioned law in 37 cases out of 42 (chromosome 5 is located in the region upstream of the HGO point, (Figure 1). The analysis below concerns cases of LOH affecting BRCA1 mutations. It is interesting to observe - even if only visually - that the effect on a female genome (XX) is greater than the effect on the same male genome (XY), which is in agreement with the fact that this cancer is almost exclusively feminine (Figure 12).

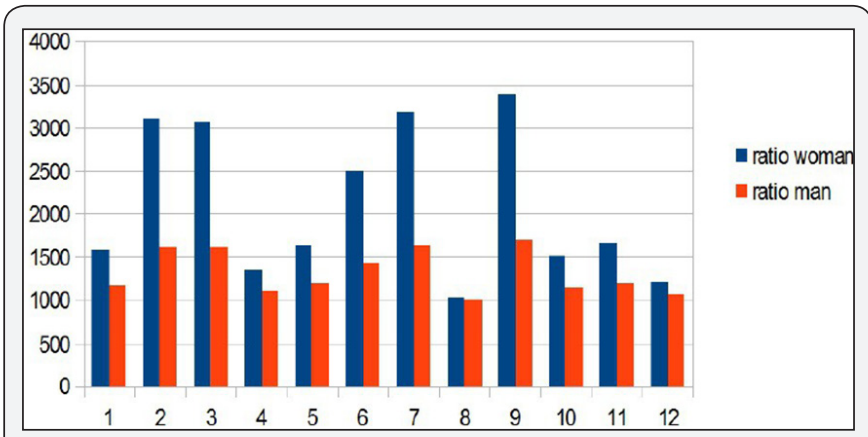

Figure 12 : Effect of LOH of chromosome 5 on the HGO ratio in breast cancers affecting the BRCA1 gene on the same genome according to whether it is female $(X X)$ or male $(X Y)$.

III. Third analysis: 72 Prostate tumors LOH in Chromosome 16:

Of 72 cases analyzed from article [25], 71 cases IMPROVED HGO while only one did not (Chromosome 16 is located in the region downstream of the HGO point, Figure 1). The evaluation below analyzes the evolution of the HGO according to the 3 grades of pathogenicity of the tumors studied:

i. Grade A: patients with disease limited to the prostate.

ii. Grade B: patients with local extracapsular extension.

iii. Grade C: patients with regional lymph node involvement or distant metastases.

iv. Between Grade A and Grade B, an average HGO improvement of $4.88 \%$ was observed [26-29].

The graph below (Figure 13) illustrates this optimization. The HGO of grade $\mathrm{C}$ is of the same order as that of Grade A, which 
may be explained by the fact that the LOHs of grades A and B are generally monochromosomes whereas the $\mathrm{LOHs}$ of grade $\mathrm{C}$ are multichromosomes [30-36]. There are therefore more complexes to be demonstrated in monochromosome studies. It is interesting to note that the effect on a female genome $(\mathrm{XX})$ is 4.86 times lower than the effect on the same male genome (XY), which is in agreement with the fact that this cancer is exclusively male (Figures $13 \& 14)$.

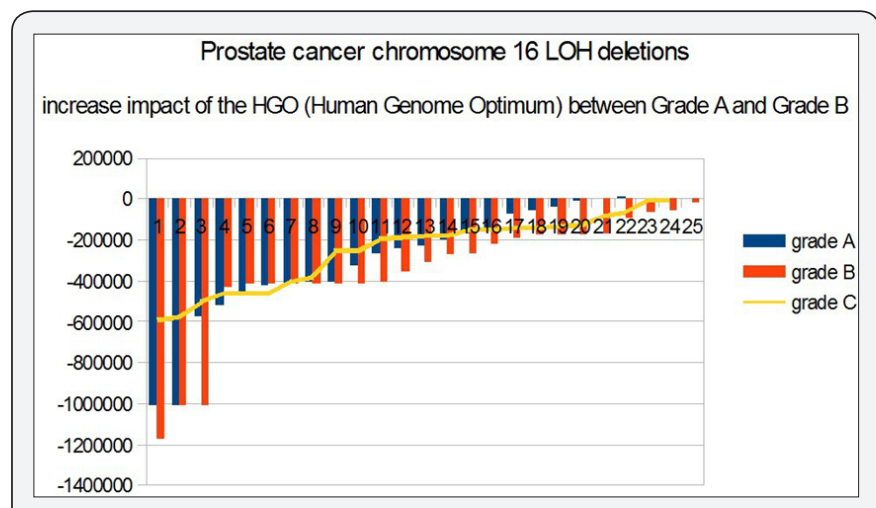

Figure 13 : Increased impact of the HGO optimality between grade $\mathrm{A}$ and grade $\mathrm{B}$ in prostate cancer involving $\mathrm{LOH}$ on chromosome 16.

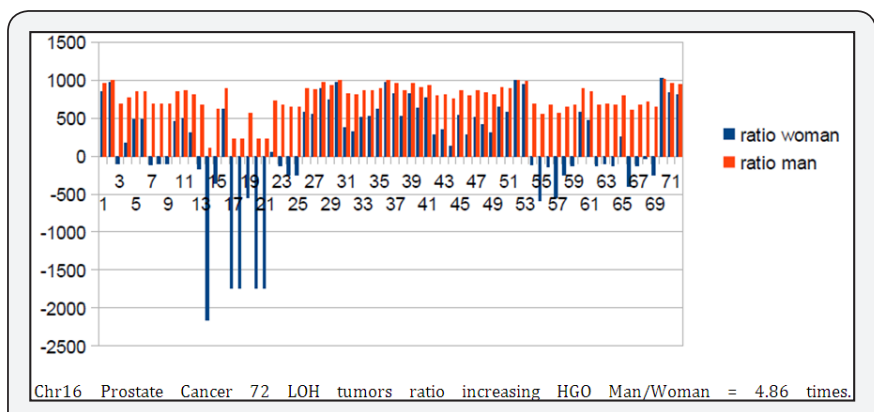

Figure 14 : Incidence of chromosome $16 \mathrm{LOH}$ on $\mathrm{HGO}$ ratio in prostate cancers on the same genome according to whether it is female $(X X)$ or male $(X Y)$.

\section{Conclusion}

It is remarkable to discover this strong correlation between the pathogenicity and the aggressiveness of tumors on the one hand, and the categorization and hierarchization of mutations $\mathrm{LOH}$ of the mutant genomes at the origin of tumors [37-42]. The law discovered here is universal, common to all types of cancers and to all chromosomes. Its nature is mathematical, proceeding only from the DNA information of the genomes. The method is exhaustive, systematic, and predictive, making it possible to anticipate the knowledge of the pathogenicity of an existing tumor or even of a mutation before the tumor disappears.

The mutant genome thus constitutes a kind of signature, virtual and numerical image of the tumor. Thus it is remarkable to discover that the LOH genome of a breast tumor, a cancer that is exclusively feminine by its nature, will lead to an overall HGO genomic degradation much greater than the same mutation affecting a male genome [43-48]. Conversely, it will be the same, but in the opposite way for a cancer of the prostate which, it is, exclusively masculine. Finally, in this same prostate cancer, the impact on HGO between grade $A$ and grade $B$ is significant: recall:

i. Grade A: patients with disease limited to the prostate.

ii. Grade B: patients with local extracapsular extension.

iii. Grade C: patients with regional lymph node involvement or distant metastases.

iv. Between Grade $\mathrm{A}$ and Grade $\mathrm{B}$, an average HGO improvement of $4.88 \%$ was observed.

To conclude, the most important fact is the universal character of this HGO law, presented here for both breast and prostate cancers, the universal character of this law has been widely generalized experimentally on a large number of cancers differences affecting most chromosomes, this generalization will be described in. "The Human Genome Optimum" (HGO): Towards a Universal Law Controlling All Human Cancer Chromosome LOH Deletion (Loss of Heterozygosity) accepted for publication in the Global Journal of Medical Research [49].

a. We still have a lot to discover on this fascinating CODE that is DNA...

b. To conclude, it is difficult to fully understand the extent of this discovery:

c. -At the theoretical level it seems fascinating that there exists this perfect digital fit of the whole genome around this sort of digital attractor.

d. At the theoretical level again, one will note the universality of the HGO law, which applies to ALL the cancers.

At the applied level, the correlation between this law and the increasing degrees of pathogenicity of the tumors is remarkable. It is thus well understood that the mechanism of invasive pathogenicity of a tumor is because its genome is more optimal than that of a healthy cell. Its immediate application is the prioritization of tumor pathogenicity stages. In this study we have just raised a new corner of sail on DNA and the human genome. A jump was the discovery of the fractal nature of DNA $[2,28]$ or certain structures of the brain [29]. Thus, mathematics has become imbedded in genetics. Other mathematical approaches to genomes, which are equally original, are to be noted with approaches to matrix [30] or mathematical topology [31]. Then it is frankly a hypothetical « quantum theory of DNA information» that invites itself into DNA [32]. And, of course, there is the famous golden ratio and its Fibonacci numerical patterns. They're not only found in the rhythms of the heart and in the arborescence of our arteries [33], but also in the RNA [34] or in quantum physics [35].

Finally, like these different researchers, we have just demonstrated how the "CODES" [36] are at the heart of the mechanisms of Nature."Codes" real today ... "Codes" artificial tomorrow [37]. As demonstrated in [38], a substantial fraction of mutations in human cancer are attributable to random errors 


\section{Cancer Therapy \& Oncology International Journal}

occurring during DNA replication. Therefore, we think that our « long range human genome law » controling cancer mutations are probably important... In [15, 39, 40-42,44-48] we will present other "hidden mathematical codes" that organize the DNA sequences of the human genome.

However, the major conclusion seems to be the following:

All the human genetic heritage is concentrated in 2 genomes: the nuclear genome and its 23 pairs of chromosomes on the one hand, and the small mitochondrial genome mtDNA, on the other hand. The majority of mutations associated with genetic diseases as well as all cancers most often lead to deletions affecting each of these 2 genomes [50-52]. Then, in the article "Sapiens mtDNA circular long-range numerical meta-structures are highly correlated with mtDNA diseases mutations" [39], as in the present article, we demonstrate that all these mutations unbalance, for both genomes, a kind of optimum of each of these genomes. This is probably the major result that we will have to continue to reflect on and experiment with. Finally, our approach may be related to these hundreds of unpredictable mutations resulting from manipulation of genomes by CRISPR revolutionary technology [43]. Effectively in their 2017 article, authors.

Note that « .../...They found that the technique had successfully corrected a gene that causes blindness in the mice, but the two mice that had undergone CRISPR gene-editing had sustained more than 1,500 unintended single-nucleotide mutations, and more than 100 larger deletions and insertions .../...».

\section{Acknowledgement}

We especially thank Dr. Robert Friedman M.D. practiced nutritional and preventive medicine in Santa Fe, New Mexico, woldwide expert on Golden ratio Life applications (https://www.amazon. com/Golden-Ratio-Lifestyle- Diet-Potential/dp/0975280252). We also thank the mathematician Pr. Diego Lucio Rapoport (Buenos aires), the french biologist Pr. François Gros (Pasteur institute, co-discoverer of RNA messenger with James Watson and Walter Gilbert ) and Pr. Luc Montagnier, medicine Nobel prizewinner for their interest in my research of biomathematical laws of genomes.

\section{Conflicts of Interest}

None

\section{Ethics Approval}

Not applicable.

\section{Consent for publication}

Not applicable.

\section{Availability of data and Materials}

Not applicable.

\section{Funding}

None.
Competing Interest

None.

\section{Competiting Interest}

None.

\section{Reference}

1. Keiichiro Suzuki, Yuji Tsunekawa, Juna Carlos lzpisua Belmonte, et al. (2016) In vivo genome editing via CRISPR/Cas9 mediated homologyindependent targeted integration. Nature 540: 144-149.

2. Lieberman-Aiden E, Van Berkum NL, Williams L, Imakaev M, Ragoczy $\mathrm{T}$, et al. (2009) Comprehensive mapping of long-range interactions reveals folding principles of the human genome. Science 326(5950): 289-293.

3. Perez JC (1991) Chaos DNA and neuro-computers: a golden link. Speculations in Science and Technology 14: 336-346.

4. Marcer PJ (1992) Order and chaos in DNA - the Denis Guichard Prizewinner: Jean-Claude Perez. Kybernetes 21(2): _60-61.

5. Perez JC (1997) L'adn Décrypté. Resurgence publisher Liege, Belgium.

6. Perez JC (2009) Codex Biogenesis. Resurgence, Liege, Belgium.

7. Petr Smarda, Petr Bures, Lucie Horova, Ilia J Leitch, Ladislav Mucina, et al. (2014) Ecological and evolutionary significance of genomic GC content diversity in monocots. PNAS 111(39): E4096-E4102.

8. Bernardi G (2007) The neoselectionist theory of genome evolution. Proc Natl Acad Sci USA 104(20): 8385-8390.

9. Bernardi G (2000) Isochores and the evolutionary genomics of vertebrates. Gene 241(1): 3-17.

10. Perez JC (2010) Codon Populations in Single-Stranded Whole Human Genome DNA Are Fractal and Fine-Tuned by the Golden Ratio 1.618. Interdiscip Sci_2(3): 228-240.

11. Perez JC (2011) Caminos Interdisciplinaios. Seminario Clave_Inter, Espacio Interdisciplinario, Universidad de la Republica Montevideo, Uruguay, South America.-

12. Perez JC (2011) Decoding Non-Coding DNA Codes: Human Genome Meta-Chromosomes Architecture. BIT Life Sciences' 3rd Annual World Vaccine Congress, Beijing, China.-

13. Perez JC (2013) The 3 Genomic Numbers Discovery: How Our Genome Single-Stranded DNA Sequence Is Self- _Designed as a Numerical Whole. Applied Mathematics 4: 37-53.

14. Perez J (2015) Deciphering Hidden DNA Meta-Codes -The Great Unification \& Master Code of Biology. J Glycomics Lipidomics 5:131.

15. Perez JC (2017) Fractal Self-similarity, Scale Invariance and Stationary waves Codes Architecture Human Chromosomes DNA sequences. Bioinformatics and Computational Biology Letters 1(1): 1.

16. Kay prufer, Fernando Racimo, Svante Paabo (2014) Neanderthal genome. Nature 505: 43-49.

17. Finishing the euchromatic sequence of the human genome (2004) nature 431: 931-945.

18. Sapiens HG38 (2013) Human genome Overview. Genome Reference Consortium.

19. Venter JG (2016) Deep Sequencing of 10,000 Human Genomes.

20. Eiriksdottir G, Johannesdottir G, Ingvarsson S, Björnsdottir IB, Jonasson JG, et al. (1998) Mapping loss of heterozygosity at chromosome 13q: loss at 13q12-q13 is associated with breast tumour progression and poor prognosis Eur J Cancer 34(13): 2076-2081. 


\section{Cancer Therapy \& Oncology International Journal}

21. Hrefna K Johannsdottir, Jonsson G, Johannesdottir G, Agnarsson BA, Eerola $\mathrm{H}$, et al. (2006) Chromosome 5 imbalance mapping in breast tumors from BRCA1 and BRCA2 mutation carriers and sporadic breast tumors. Int J Cancer 119(5): 1052-1060.

22. Fujisawa H, Reis RM, Nakamura M, Colella S, Yonekawa Y, et al. (2000) Loss of Heterozygosity on Chromosome 10 Is More Extensive in Primary (De Novo) Than in Secondary Glioblastomas. Lab Inves 80(1): 65-72.

23. Hironori Fujisawa, Rui M Reis, Mitsutoshi Nakamura, Stefano Colella, Yasuhiro Yonekawa, et al. (2000) Loss of Heterozygosity on Chromosome 10 Is More Extensive in Primary (De Novo) Than in Secondary Glioblastomas. Laboratory Investigation 80: 65-72.

24. Sam Thiagalingam, Steve Laken, James KV Willson, Sanford D Markowitz, Kenneth W Kinzle (2001) Mechanisms underlying losses of heterozygosity in human colorectal cancers. Proc Natl Acad Sci U S A 98(5): 2698-2702.

25. Mora J, Cheung NK, Kushner BH, LaQuaglia MP, Kramer K, et al. (2000) Clinical Categories of Neuroblastoma Are Associated with Different Patterns of Loss of Heterozygosity on Chromosome Arm 1p. J Mol Diagn 2(1): 37-46.

26. Latil A, Cussenot O, Fournier G, Driouch K, Lidereau R (1997) Loss of heterozygosity at chromosome $16 \mathrm{q}$ in prostate adenocarcinoma: identification of three independent regions. Cancer Res 57(6): 10581062 .

27. Wolf-Hirschhorn syndrome (2017) Genetics Home Reference, NIH US National Library of Medicine.

28. Friedman R, Cross M (2013) The Golden Ratio \& Fibonacci Sequence: Golden Keys to Your Genius, Health, Wealth \& Excellence. $1^{\text {st }}(\mathrm{edn})$, Hoshin Media, USA.

29. Pellionisz AJ, Graham R, Pellionisz PA, Perez JC (2012) Recursive Genome Function of the Cerebellum: Geometric Unification of Neuroscience and Genomics. In: Manto M, DL (Eds.), Handbook of the Cerebellum and Cerebellar Disorders. $1^{\text {st }}$ (edn.), Springer, USA.

30. Dokukin ME, Guz NV, Woodworth CD, Sokolov I (2015) Emergence of fractal geometry on the surface of human cervical epithelial cells during progression towards cancer. New J Phys 17(3).

31. Petoukhov S (2011) Mathematics of Bioinformatics: Theory, Methods and Applications. $1^{\text {st }}(\mathrm{edn})$, John Wiley \& Sons, USA.

32. Rapoport DL (2015) Möbius strip and Klein Bottle Genomic Topologies, Self reference, Harmonics and Evolution, Life.

33. Diego Rapoport (2016) Reference Heterarchies Genomic Topologies Harmonics and Evolution. Part III The Klein Bottle Logic of Genomics and its Dynamics Quantum Information Complexity and Palindromic Repeats in Evolution.

34. L Montagnier, J Aissa, A Capolupo, TJA Craddock, P Kurian, et al. (2017) Water Bridging Dynamics of Polymerase Chain Reaction in the Gauge Theory Paradigm of Quantum Fields. Water 9(5): 339.

35. Persaud, Dharam, O'Leary James P (2015) Fibonacci Series, Golden Proportions, and the Human Biology HWCOM Faculty Publications. Austin publishing Group 2(5): 6.
36. Hengwu Li, Daming Zhu, Caiming Zhang, Huijian Han, Keith A Crandall (2014) Characteristics and Prediction of RNA structure. BioMed Research International p. 10.

37. Vaezi A, Barkeshli M (2014) Fibonacci Anyons From Abelian Bilayer Quantum Hall States. Phy Rev Lett_ 113(23): 236804.

38. Marshall P (2015) Evolution 2.0. Benbella Books, USA.

39. Roman V Yampolskiy (2017) On the origin of synthetic life: attribution of output to a particular algorithm. Phys Scr 92(1).

40. Cristian Tomasetti, Lu Li, Bert Vogelstein (2017) Stem cell divisions, somatic mutations, cancer etiology, and cancer prevention Science 355(6331): 1330-1334.

41. Perez JC (2017) Sapiens Mitochondrial DNA Genome Circular Long Range Numerical Meta Structures are Highly Correlated with Cancers and Genetic Diseases mtDNA Mutations. J Cancer Sci Ther 9: 512-527.

42. Perez (2017) DUF1220 Homo Sapiens and Neanderthal fractal periods architectures breakthrough (2017) SDRP Journal of Cellular and Molecular Physiology 1(1).

43. Perez JC (2017) Humans and Primates Chromosomes4 Fractal CODES periodic stationary waveforms charaterizing and differentiating Neanderthal and Sapiens whole chromosomes DNA sequences.

44. Perez JC (2017), Symmetry and Asymmetry in the MENDELEEV's Periodic Table Predictive EQUATION. SDRP Journal of Computational Chemistry \& Molecular Modelling 2(1).

45. Kellie A Schaefer, Wen-Hsuan Wu, Diana F Colgan, Stephen H Tsang, Alexander G Bassuk, et al. (2017) Unexpected mutations after CRISPRCas9 editing in vivo. Nature Methods 14: 547-548.

46. Perez JC (2017) Decyphering the MASTER CODE ® Structure and Discovery of a Periodic Invariant Unifying 160 HIV1/HIV2/SIV Isolates Genomes. Biomed J Sci \& Tech Res 1(2)

47. Perez JC (2017) The Master Code of DNA: Towards the Discovery of the SNPs Function (Single-Nucleotide Polymorphism. J Clin Epigenet 3: 26

48. Perez JC (2017) The Master Code of Biology:Self-assembly of two identical Peptides beta A4 1-43 Amyloid in Alzheimer's Diseases. Biomed J Sci \& Tech Res 1(4).

49. Perez JC (2017) The «Master Code of Biology»: from Prions and Prionslike Invariants to the Self-assembly Thesis. Biomed J Sci \& Tech Res $1(4)$

50. Perez JC (2017) Why the genomic LOCATION of individual SNPs is FUNCTIONAL?(2017)SDRP Journal of Cellular and Molecular Physiology 2(1)

51.Perez JC (2017) The Human Genome Optimum (HGO): Towards a Universal Law controlling all Human Cancer Chromosome LOH Deletions (Loss of Heterozygosity). Global Journal of Medical Research $17(6)$.

52. Perez JC (2017) CRISPR Technology Challenge Facing the Numerical Integrity of Whole Human Genome DNA. MOJ Biol Med 1(6): 00037. 
This work is licensed under Creative Commons Attribution 4.0 License

DOI: $10.19080 /$ CTOIJ.2018.09.555756
Your next submission with Juniper Publishers will reach you the below assets

- Quality Editorial service

- Swift Peer Review

- Reprints availability

- E-prints Service

- Manuscript Podcast for convenient understanding

- Global attainment for your research

- Manuscript accessibility in different formats

( Pdf, E-pub, Full Text, Audio)

- Unceasing customer service

Track the below URL for one-step submission https://juniperpublishers.com/online-submission.php 